Japanese Research in Business History 2019 | 36

\title{
Labor Oral History in Japan
}

\author{
Osamu UMEZAKI
}

Hosei University

\begin{abstract}
The purpose of this article is to present a comprehensive picture of labor oral history studies which have accumulated in Japan and to show labor oral history's possibility to bring new aspects into research. Labor oral history studies have accumulated to a considerable extent in Japan over the years, to which the author has made a small contribution. Although the author's document retrieval is not complete, this article would encourage historians to utilize Japanese oral histories as it gives their general outline to researchers both within and outside the country.
\end{abstract}

Keyword: oral history, labor history, industrial relations, methodology

\section{Introduction}

The purpose of this article is to present a comprehensive picture of labor oral history studies which have accumulated in Japan and to show labor oral history's possibility to bring new aspects into research. Oral history is defined as "the act of making a record of past experiences in the form of a narrative through collaboration between the interviewer and the storyteller, or transcripts made and preserved in such a way."

In terms of the utilization of historical narratives for the purpose of describing history, oral history also includes certain types of oral traditions. From this point of view, Kojiki [An account of ancient matters], the oldest historical account in Japan, can also be regarded as oral history. If the range of oral history is taken too widely, however, it would be too difficult to present a comprehensive view of oral history researches. Therefore, this article leaves oral traditions out of consideration and focuses only on the field of Japanese labor history, in which the author specializes.

Even before oral history became a commonly used term among historical researchers, they had already adopted the de facto oral history method in the names of "shidan [historical story]," "shogen kiroku [testimony]," "kikigaki [dictation]" and so on. It can be said therefore that oral history is a rather old research method. As a matter of fact, however, too much importance has been laid upon written documents in academic research of history, against which criticism is often raised even today. In addition, oral history has a potential to produce research results which would shed a light on new aspects of historical events. Therefore, it is worth reevaluating this old method as a "new approach" to historical investigation.

The primary reason why oral history has now become adopted as a research method for any historical subject is that otherwise the research would be biased. That is, if researchers use written documents alone, history would be described only on the basis of records left by those who were able to

Japanese Research in Business History, vol. 36, 2019, pp.4-31

Correspondence to E-mail: umezaki@hosei.ac.jp

@2019 Business History Society of Japan 
wright, or publish what they wrote. In the case of labor history, for example, records of management board members, top administration officials, politicians, officers of national centers and leaders of industrial unions are likely to be preserved. Whereas, experiences of rank-and-file workers are hardly recorded in written documents. Moreover, even if a study is attempted concerning a labor-management negotiation with a focus on the behaviors of management executives and union leaders, it will be found that written documents convey only publishable information and that information on delicate subjects such as the decision making process within each camp remains concealed.

Of course, people do not tell all their opinions, or experiences, if they agree to the interview, and if they tell, they do not necessarily give permission to publish. ${ }^{1}$ Nevertheless, however, oral history does extend the range of historical investigation.

Even though oral history has merits as abovementioned, the fact remains that the academic discipline of history still places priority on written documents. There are two types of criticism against oral history.

First, there is criticism against the inaccuracy of narratives. Itō Takashi has conducted an overwhelming amount of oral history research in the field of political history with the belief that oral history is a valuable historical material. However, even he holds that "the importance of oral history as a source of historical study is only secondary, even if it is conducted by an excellent interviewer with a person with an excellent memory" (Itō 2009, 17). Nakamura Masanori, Itō's contemporary and a forerunner of oral history research in economic history, also maintains: "I give oral history a complementary role to written documents" (Nakamura 1987, 4). Although these two historians differ in research field and ideological stance, contemporaneity can be recognized in the methodology they both adopted in their attempts to rebuild empirical research of history after the War. ${ }^{2}$

Ito points out two reasons why oral history is of secondary importance. The first reason is the inaccurate nature of memory. The second is that a story of remembrance is reconstructed during the interview. This type of criticism from the standpoint of objectivism exists even today. However, to take into consideration the trends in present-day history studies such as radical social constructionism and the "linguistic turn" that stress the autonomy of language, ${ }^{3}$ the belief that we have access to past events only through written documents is considered naïve objectivism.

Though the argument here does not go into details about ontological, or epistemological, problems concerning fact and historical evidence, it needs to be emphasized that inaccuracy concerning historical materials is only a "matter of degree" and that there is no crucial difference between written and narrative sources.

In the case of written documents, the effects of memory lapse and the extent to which past experiences are rewritten are relatively small, because the time distance between a historical event and the production of documents of it is usually not so long. However, written documents include records based on recollection and they are not completely relieved of memory lapse. On the other hand, oral

\footnotetext{
${ }^{1}$ Umezaki (2016 a) points out that the range of the storyteller's memory is broader than the range of what is told during the interview, which is broader than the range of what is made open to the public. Therefore, it is necessary for the interviewer to build a trustful relationship with the interviewee.

2 "Contemporaneity" here means that both scholars not only aimed at a scientific grasp of history as against the emperor-centered historiography of the pre-war period but also sought to comprehend "human beings" rather than to analyze "structure" as Marxism did. For that purpose, they both chose to use "(the criticism of) historical records," which they thought was the strength of "history" that "literature" lacked.

${ }^{3}$ See, for instance, Odanaka (2000) and Ueno (2001).
} 
history has research methods such as the simultaneous oral history method, according to which interviews are conducted immediately after a historical event. Therefore, the demarcation based on the "written/spoken" difference cannot be rigidly defined despite its ostensible persuasiveness.

The second criticism against oral history studies is that they are not open to source criticism, because many of oral history records are not made open to the public. In the author's opinion, this problem related to open accessibility of oral records is the most fundamental reason why this "hearing" method is used only complementarily in history research whereas it has been established as a standard research method in ethnology and sociology.

The Western-style Modern history was introduced to Japan during the Meiji period at the same time as the foundation of universities. This academic discipline was established in nineteenth-century Europe, and as its characteristic methodology based on scientific thought it espoused source criticism. As Chizuka Tadami points out, many historical propositions are difficult to prove by repeated examinations, because subjects of history research are past events that never repeat themselves (Chizuka 2010). By contrast, in academic fields where experiments and repeated inquiries are possible, a proposition made by a researcher can be falsified by another relatively easily. Moreover, if the research subject in question is not an once-in-history event, conclusions of previous studies can be supported, or falsified, by investigating similar events even through the interview method.

In the case of history research, however, past experiences can be approached only through historical records, and research subjects are mostly singular events. Even historical records have their own problem: that is, the demarcation line between "objective" fact and "interpretative (subjective)" fact is blurred (Chizuka 2010,8). Because of these problems, modern history as an academic discipline based on empiricism necessitated "researchers' community" in which researchers checked each other's interpretations on the basis of empirical records so that dogmatic interpretations were refuted. In short, it is not either written or spoken but either open or closed that is crucial for empirical research of history. ${ }^{4}$ Therefore, if the storyteller revised his/her story (this can also happen in the case of written documents), the only necessary thing is to publish the revised version so that researchers can cite the new version in their studies. ${ }^{5}$ If the citation is part of the whole record, other researchers can decide whether the interpretation of the cited part is contextually appropriate.

Incidentally, Ōkado Masakatsu points out that while Japan's academic history research based on positivism, which focused mainly on political history, was taking root at universities during the Meiji period, interviews with former senior officials of the Tokugawa administration started in 1891, asking them about unwritten truths regarding events that had happened during the Tokugawa period. Such interviews later became known as "Kyūji Shimonkai [Investigative hearings on past events]." It should be noted that the oral history method was adopted in modern Japanese history research at such an early stage.

In retrospect, Japanese historians with their eager desire to understand the past used to be rather keen on applying the oral history method to their investigations. As history studies accumulated, however, they became reluctant to use the method. This reluctance is still found among historians even today notwithstanding the attractiveness of oral history. For instance, business historians conduct interviews, when they are involved in the publishing work of companies' and organizations' histories.

\footnotetext{
${ }^{4}$ Of course, the mere fact that source criticism is made possible among researchers does not necessarily mean that objectivism is prevalent.

${ }^{5}$ It should be borne in mind that storytellers may change their stories, or do not speak at all, if it is predetermined that their stories are given open accessibility.
} 
By contrast, however, they are reluctant to use oral histories as primary sources when they write academic papers, because they are not open to source criticism.

The stance of making oral history records "more open to the public" would be criticized by ethnologists, anthropologists and sociologists as rather "too much positivism." That is contrary to the criticism from historians believing in written documents that oral history is "not a method of positivism." The author is of the opinion that unless oral history records is made more open to the public in order to answer the latter criticism, the role of oral history in academic research will remain only a complementary one however many oral history studies are implemented.

In previous studies, the author has examined the methodology of oral history (Umezaki 2012) and given an introduction to labor oral history studies which have accumulated in Japan (2007). In addition, a report has been made on an attempt to create an oral history archive. (Umezaki 2016). To these previous inquiries, this article adds latest information and new observations.

\section{Classification Criteria for Oral History}

In what follows will be given an overall picture of Japanese labor oral history studies. Labor oral history studies have accumulated to a considerable extent in Japan over the years, to which the author has made a small contribution. Because many of the earlier studies do not include the term, "oral history," in their titles, all the oral history studies cannot be retrieved by database searching. This article seeks to present an comprehensive picture of Japanese labor oral history studies, although it cannot be a complete one. ${ }^{6}$

First of all, in order to sort out a large number of labor oral history studies, classification criteria are set in advance. The first criterion is whether or not it is a history study. In other academic disciplines such as ethnology and sociology, the interview method is also applied frequently in inquiries handling historical subjects. The method is commonly called "kikigaki" [dictation] in ethnology and "life history (or, life story)" in sociology. Moreover, non-academic historians such as non-fiction writers and journalists also use the interview method when they deal with topics related to labor history. Reflecting the author's specialty, this article mainly handles academic studies. However, works in related fields are also referred to when necessary.

Second, there is a difference between oral histories implemented as studies of labor history and oral histories concerning labor issues that are part of studies in other academic fields such as modern history. In the former case, such oral histories can be found relatively easily in a database, because researchers who conducted interviews are labor historians and the titles of research projects usually include key words such as "trade union" and "human resources management." In the latter case, however, oral evidence constitutes only a part of the entire inquiry. So, individual storytellers' biographical notes have to be checked when conducting document retrieval. As a matter of fact, it is very difficult to find all the labor oral history studies in a database.

The third criterion is whether or not the author participated in the oral history research project in question. Given the difficulty in retrieving labor oral history studies through database searching, the explanatory weight cannot help being placed on research projects the author himself planned, or participated in. In addition, more detailed explanation can be provided for such researches. With regard to

\footnotetext{
${ }^{6}$ As for labor oral history studies in Britain, Paul Thompson's monumental work (Thompson 2000) gives an introduction.
} 
the research projects in which the author took part, therefore, elucidation will be given separately in an independent section.

\section{An Exploration into the History of Oral History}

\section{Documentary Literature and Journalism}

As abovementioned, only a complementary role has been assigned to oral history as the academic discipline of modern history has accumulated empirical studies. In contrast to academic historians believing in written documents, it was non-fiction writers with their eyes set on "lived experience" of workers unable to leave written documents that produced appealing results by making active use of the interview method. Masterpieces of documentary literature on labor history were made during the 1960s by writers keen on conveying workers' experiences themselves in spoken language. Unconstrained by academism, they actively adopted the interview method. Exemplary works such as Owareyuku Köfutachi [Miners driven away] (Tokyo: Iwanami Shoten, 1960) and Chi no Soko no Waraibanashi [Funny stories under the ground] (Tokyo: Iwanami Shoten, 1967) by Ueno Eishin, Makkura Onna Köfu karano Kikigaki [Darkness: Hearings from female miners] (Tokyo: Rironsha, 1961) by Morisaki Kazue and Aa Nomugi-tōge [Oh! The Nomugi Pass: A tragic history of female silk spinners] (Tokyo: Asahi Shinbunsha, 1968) by Yamamoto Shigemi, all written during the period of Japan's high economic growth, depict experiences of those who sustained, by their hard labor and tough lives, the country's economic development after the Meiji Restoration. ${ }^{7}$

While acknowledging the significance of these works, academic historians seem to have held that non-fiction literature and historical research are qualitatively different. ${ }^{8}$ It come as no surprise that they have reservations about the genre's two-faced nature of factuality and creativeness, even if they recognize its merits. In addition, since such documentaries are published as works of literature, they are hardly regarded as historical records.

For instance, Nakamura Masanori, an oral history forerunner in Japan, first adopted the method when he wrote Nihon no Rekishi 29 Rōdōsha to Nömin [The history of Japan 29: Workers and farmers] (Shōgakkan: 1976). He relates in the afterword of this book: "After having pondered on how to do it, I decided to try the dictation method, which I had developed for more than a decade." (Ibid: 493) In other words, Nakamura had been discreet in applying that method, although, in practice, he had been rather actively using it. As a matter of fact, he uses the oral history method only complementarily in the book. In his later work, Shōwa no Kioku o Horiokosu: Okinawa, Manshū, Hiroshima, Nagasaki no Kyokugen Jōkyō [Digging into memories: Extreme situations in Okinawa, Manshū, Hiroshima and Nagasaki] (Shōgakkan: 2008), he admits that he has changed his research style, giving preference to oral over written records (Ibid: 265). It took a long time for him to change his research style.

There are also a large number of interview-based documentaries produced by non-academic historians. For example, Ashio ni Ikita Hitobito [People who lived in Ashio] (Utsunomiya: Zuisōsha, 2000) by Murakami Yasumasa is an excellent book and historical record comprising interviews of those who lived in Ashio and worked at the Ashio Copper Mine. The interviews were conducted by

\footnotetext{
7 Attempts by non-academics to write oral history works became popular in fields such as women's history and regional history, and produced some monumental works. The increased interest in people previously out of scope of traditional history research was concomitant with the popularization of oral history in the United States. See Uesugi (1988) for details.

${ }^{8}$ In the latter half of the $1980 \mathrm{~s}$, there was a movement in the academic history circle in which researchers tried to learn from non-fiction writers and journalists. (Rekishigaku Kenkyūkai 1988 a and b)
} 
the author who himself had worked for the Furukawa Mining. Another example is Nozoe Kenji, who has produced many interview-based documentaries on the labor and technological history of forestry and hunting in provincial areas in his native Akita Prefecture. (For example, Akitasugi o Hakonda Hitotachi - Shōki Tōhoku Ringyō no Bunka Rōdōshi (Michinoku Tami no Katari) [People who transported Akita Cedar - A detailed cultural and labor history of forestry in the Tōhoku district] (Tokyo: Shakai Hyōronsha, 2006)). A comprehensive list of such interview-based documentaries is yet to be made.

Next, there are oral history books consisting of interviews conducted by journalists. The books cited below are not so much documentary literature as introductions to historical records, even though they are meant to be read as stories. First, there are memoirs such as Shōgen Sengo Rōdō Undōshi [Testimonies: The post-war labor history] (Tōkai University Press: 2003) by Takaragi Fumihiko and Kaisō no Yomiurisōgi [Recollecting the Yomiuri Labor Dispute] (Shin'nihon Shuppansha, 1994) by Miyamoto Tarō. The former is a story about the period between the labor movement of the Zentei (Japan Postal Workers' Union) and the unification of the labor front, and the latter, about the labor dispute at the Yomiuri Newspaper. In addition, activities of industrial unions and national centers can be known from Shōgen Kōsei Sengo Rōdō Undōshi [The collection of testimonies: The post-war labor history] (Sengo Rōdō Undōshi Hanpukai, 1991) edited by Morooka Takeo and Naka Mamoru and Shōgen Sōhyō Rōdō Undō [Testimonies: The Sōhyō labor movement] (Sōhyō Center, 1990) edited by Sōhyō Shinbunsha. Moreover, Keiei Leader no Shōwa Rōmushi [The history of labor management in the Shōwa period recounted by managerial leaders] (Nikkeiren Kōhōbu, 1990) edited by Yakabe Katsumi gives testimonies to the history of labor management. With regard to these oral history books, however, there is a high possibility that actually told stories were edited, or abbreviated, to a substantial extent, because they were published on a commercial basis.

\section{Labor Oral History Studies by Academic Historians}

\section{(1) Organized Oral History Projects}

Among oral history studies implemented by labor historians for the purpose of labor history research, those carried out as organized projects are introduced first: Namely, oral history projects organized by the Ōhara Shakaimondai Kenkyūsho [Ōhara Institute for Social Research, Hōsei University], the Nihon Rōdō Kenkyū Kikō [Japan Institute for Labour Studies] (present-day, Rōdōseisaku Kenkyū Kenshū Kikō [Japan Institute for Labour Policy and Training]) and the Osaka Shakaiundō Kyōkai [Association for Social Movements in Osaka]

With regard to oral history research projects organized by the Ōhara Institute for Social Research, Yoshida Kenji, who himself has participated in such projects as an interviewer, gives an outline. (The following is based on Yoshida (2009).) The starting point of the Institute's oral history projects was the one called "Wagakuni Rōnōundō ni okeru Shakai Minshushugi no Kenkyū [An inquiry into social democracy in Japan's workers' and farmers' movements]" set up in 1960. In this project, leaders of legal proletarian parties and those of workers' and farmers' movements as well as persons associated with the Japanese Communist Party were interviewed. Although the audio records and transcripts still exist, they have not been made open to the public. Then, in 1969 started the publication of Fukkoku Series: Nihon Shakai Undō Shiryō [Republication Series: Records of Japanese Social Movements]. Although interviews were conducted for the publication of the series, neither the publication nor the preservation of their records were intended at the time. It can be said, therefore, that despite its recognition of oral history's importance, the Institute was less interested in the publication and preservation 
of oral history records than the publication and preservation of written documents. Oral history research was considered complementary to the analysis of written documents.

A major turning point was the setting-up of the "Sanbetsu Kaigi Kenkyūkai [Research Association for the Congress of Industrial Unions]" in 1979. The main tasks of this research project was to conduct interviews with leaders of the Sanbetsu Kaigi [Congress of Industrial Unions] and Zenrōren [the National Confederation of Trade Unions] and to edit and publish them. Then, when the "Sengo Shakaiundō no Fukkoku ni kansuru Chōsakenkyū Project [Research Project on the Revival of Social Movements in Post-war Japan]" was launched in 1989, it had been predetermined that the planned interviews be published and preserved.

As of 2019, the following oral history books have been published with the involvement of the Ōhara Institute as an editor: Shōgen Sanbetsu Kaigi no Tanjō [Testimonies: The Birth of the Congress of Industrial Unions] (Tokyo: Sōgō Rōdō Kenkyūsho, 1996); Shōgen Sanbetsu Kaigi no Undō [Testimonies: Activities of the Congress of Industrial Unions] (Tokyo: Ochanomizu Shobō, 2000); and Shōgen Senryōki no Sayoku Media [The left-wing media during the occupation period] (Tokyo: Ochanomizu Shobō, 2005). In addition, Nihon Shakai-tō Sōhyō no Kiseki to Naijitsu (20-nin no Oral History) [The trajectory and real state of the Japan Socialist Party and the General Council of Trade Unions of Japan (oral histories of twenty persons)] (Tokyo: Junpōsha, 2019) edited by Igarashi Jin and Kinoshita Masashi should also be cited. Since commercial publication cannot avoid the problem of space limitations, the Institute has disclosed a lot of information through other channels: that is, Ōhara Shakaimondai Kenkyūsho Zasshi [Journal of the Ōhara Institute for Social Research] and other working papers.

Second, oral history research projects organized by the Nihon Rōdō Kenkyū Kikō [Japan Institute for Labour Studies] have been implemented through the "Sengo Rōdōkumian Undō no Shōgen Kenkyūkai [Research Association for Testimonies regarding the Post-war Trade Union Movement]" (1992 - 2001) set up by Takanashi Akira, who was then Shochō [Director] of the Institute at the time and later became Kaichō [President]. This Association too conducted many interviews with trade union leaders. However, as was the case with the Ōhara Institute, the contents of the interviews was kept secret at the time of the inquiries. The disclosure of information was long overdue, with the only exception of Sengo Rōdō Kumiai Undō no Rekishi - Bunretsu to Tōitsu - "Ōta Kaoru Moto Sōhyō Gichō" Shōgen [The history of the trade union movement in post-war Japan - breakup and unification - The testimony of Ōta Kaoru, former Chairman of the General Council of Trade Unions of Japan] (Nihon Rōdō Kenkyū Kikō, 1999). It was not until 2003 when Sengo Rōdō Kumiai Undō no Rekishi - Bunretsu to Tōitsu Dai 1-5shū [The history of the trade union movement in post-war Japan - breakup and unification, vols. 1-5] were published that the records were made accessible to outside researchers. These books consist of testimonies concerning the breakup and unification of trade unions during the period between 1950 and1989. Apart from this project, the Institute has also implemented oral history studies regarding "industrial relations in different industries" and "labor administration and policies on labor law." However, they have not been made open to the general public. As of now, incidentally, the Japan Institute for Labour Policy and Training has decided not to launch a new historical research project.

The projects organized by the Japan Institute for Labour Studies is valuable in that they are a comprehensive collection of interviews including many trade union leaders whose stories we are no longer able to hear now. The problem is, however, that it is difficult to read and understand the transcripts of these interviews. Since former trade union officials and office staff assume the role of interviewers in most of the cases, the interviews are, if fact, conversations between experienced unionists. 
In the case of oral history studies carried out by academic researchers, they assume the role of interviewers and ask questions from the standpoint of an objective third party. Whereas, in those projects, both interviewers and interviewees belong to the same inner circle of trade unions and their conversations are based on their shared experiences and expertise. This is why it is difficult to understand the contextual meanings of their remarks.

By the way, the project has a prehistory. Sengo Rōdō Kumiai Undōshi eno Shōgen [Historical testimonies to the post-war trade union movement] (Nihon Rōdō Kenkyū Kikō, 1998) edited by Takanashi Akira is, in fact, the republication in 1998 of the contents of Sengo Nihon Rōdōundōshi Kisoshiryō no Shūshūseiri Kenkyūkai [The research association for the collection of basic data regarding the post-war labor movement in Japan] (Monbu-shō Sōgōkenkyū (A), 1978). Included in this booklet are testimonies of Mito Nobuto, Kaite Shingo and Koga Atsushi. This project developed into a seminar called "Sengo Rōdōkumian Undō no Kiseki to Tenkanki o Sasaeta Shidōsha [The trajectory of the post-war trade union movement and its leaders in the period of its transition]" sponsored by the Nihon Seisansei Honbu [Japan Productivity Center]. Its contents were published as a book, Shōgen Sengo Rōdōkumian Undōshi [Testimonies: The history of the post-war trade union movement] (Tōyōkeizai Shinpōsha, 1985). This book includes testimonies of Hosoya Matsuta, Koga Atsushi, Takaragi Fumihiko, Ōta Kaoru, Wada Haruo, Amaike Seiji, Miyata Yoshiji and Seto Ichirō.

Third, the oral history project organized by the Association for Social Movements in Osaka, a public interest corporation (incorporated foundation) established in 1978 by trade unions, social welfare organizations, academics, lawyers and so on, was aimed for the publication of Osaka Shakai Rōdō Undōshi [The history of social and labor movements in Osaka]. In the process, a large number of narratives were collected regarding social and labor movements in Osaka. Some of them can be read in Osaka Rōdō Undōshi Kenkyū edited by the Osaka Shakai Rōdō Undōshi Kenkyūkai (the author has been able to confirm the publication of this magazine from the preparation issue through no. 19). However, many of them have been left in the form of simply bound booklets and cassette tapes. In "Osaka Shakaiundō Kyōkai no Oral History ni tsuite [Oral histories conducted by the Association for Social Movements in Osaka] (Ōhara Shakaimondai Kenkyūsho Zasshi, vol. 621, 2010: 53-68), Shimanishi Tomoki, Umezaki Osamu and Nagumo Chiaki has looked into these oral histories and made, with a bibliographical note, a list which includes the interviews recorded in the cassette tapes, let alone all the interviews that appear in the published magazines and thirty-two simply bound booklets.

The Tokyo Daigaku Shakaikagaku Kenkyūsho [Institute of Social Science, the University of Tokyo] is another academic institute that has been actively involved in labor studies. This institute used to implement a number of historical investigations. According to Yamamoto (2009), the Institute's oral history studies were mainly aimed at status quo analysis, even when they handled historical events. The studies were rarely published without deleting proper nouns, and most of the interviews are structured. Only a small number of the studies can be considered "oral history" that record narratives of personal experiences by means of the open-ended, or half-structured, interview method. One of such few cases is "Shiryō Meiji Taishō-ki no Zōsen Rōdōsha - Moto 'Zōkisenkōrō Kumiai' Kaichō Takayama Jiroichi tono Mensetsu Kiroku [Record: Shipbuilders in the Meiji and Taishō periods - A record of an interview with Takayama Jiroichi, former Chief Secretary of the Shipbuilders' Union]" (Shakaikagaku Kenkyū [Journal of Social Science], vol. 34-2, 1982: 181-201) by Kobayashi Ken'ichi and Yamamoto Kiyoshi. This study focuses on a personal history. The Institute also carried out interviews with twelve leaders of the Yomiuri Labor Dispute. The names of the storytellers include: Suzuki Tōmin, Shiga Shigeyoshi, Watanabe Fumitaro, Mutō Mitsunori, Masuyama Tasuke, Miyamoto Tarō, Furukawa Shin and Watabiki Kuninobu. 


\section{(2) Labor Oral History Studies Retrieved by the Author}

First of all, Shōgen Nihon Senryōshi - GHQ Rōdō-ka no Gunzō [Testimonies: The GGQ Labor Section] (Tokyo: Iwanami Shoten, 1983) by Takemae Eiji and Kikigaki Densan no Gunzō [Interviews: the Japan Electric Power Industry Labor Union] (Tokyo: Heigensha, 1992) by Kawanishi Hirosuke are exemplary oral history studies implemented by individual researchers. As historical evidence, these studies constitute a research basis on which investigations into labor policies during the occupation period and the electric power workers' dispute of 1950 are carried out. Incidentally, Kawanishi is practicing labor oral history at his university classes. Sengo Nihon no Sōgi to Ningen - Chiba Daigaku Kyōyō-gakubu no Kyōiku Jissen Kiroku [Labor disputes and people in post-war Japan - A record of an educational practice at College of Liberal Arts and Sciences, Chiba University] (Nihon Hyōronsha, 1986) and Sengoshi to Life History - Chiba Daigaku Kyōyō-gakubu no Kyōiku Jissen Kiroku [The history of post-war Japan - A record of an educational practice at College of Liberal Arts and Sciences, Chiba University] (Nihon Hyōronsha, 1992), both edited by Kawanishi Hirosuke, are valuable historical records. Although students attending his classes play the role of interviewers, proper preparations keep the quality of the interviews.

Next, Itō Takashi supervised the editorial work of Gendaishi o Kataru 3 Katsura Takashi Naiseishi Kenkyūkai Danwa Sokkiroku [Telling stories of the modern history 3 Katsura Takashi - The Research Association for the History of Domestic Administration stenographic records] (Gendai Shiryō Shuppan, 2003). The book is based on the interviews conducted by the Research Association for the History of Domestic Administration in 1973. It is a valuable record concerning the history of labor management, because Katsura Takashi is a person who was in charge of labor administration and engaged in the research and education of labor management both before and after the War.

Taguchi Kazuo and Iwasaki Kaoru produced Sonoda Yasuyoshi Oral History (Moto Nippon Kōkan Jinji-bu, Ruika Daihyō Torishimariyaku) [The oral history of Sonoda Yasuyoshi (former officer at the NKK Personnel Department, former Representative Director of the Ruika Company] and Miura Tadashi Oral History (Moto Nihon Shōgyō Rōdō Kumiai Rengōkai Kokusai-kyoku Kyokuchō) [The oral history of Miura Tadashi (former Head of International Bureau, the Japan Federation of Commercial Workers' Unions] (Kakenhi Hōkokusho [The Grants-in-aid for Scientific Research Report], 2016 and 2017). Moreover, Aoki Hiroyuki produced Kantake Nagayoshi Oral History (Moto Shin'nittetsu Hikari Kanren Kyōgichō, moto Shin'nittetsu Kanren Kyōgikai Fukugichō) [The oral history of Kantake Nagayoshi (former Chairman of the Nippon Steel Hikari Council of Related Unions, former Deputy Chairman of the Nippon Steel Council of Related Unions] (The Kagawa University Institute of Economic Research Working Paper Series, no. 218, 2018-2019).

"Series Kono Hito ni Kiku Rōshikankei [The series of interviews: Talking to this person - Industrial Relations]" serialized in Chuō Rōdō Jihō [The News Paper of the Central Labour Relations Commission] is also oral history. In this series, people associated with the Central Labour Relations Commission are interviewed by Nitta Michio, Watanabe Akira and Sugano Kazuo. From the union side, Shimada Kazuo, Matsui Yasuhiko, Hattori Mitsurō, Takagi Tsuyoshi and Suzuki Katsutoshi tell their stories. From the employers' point of view, Ogawa Yasuichi, Fukuoka Michio, Fukase Yoshirō, Sugiyama Kōichi, Katō Jōbu, Katase Toshio and Kaneko Yōko tell their side of the story. As a scholar, Hagisawa Kiyohiko also gives an account.

Hito o Ikasu! - Genba kara no Keiei Rōmushi [Making good use of human resources - The history of labor management at worksite] (Nikkeiren Shuppan-bu, 2002) by Fukuoka Michio is a collection of oral histories regarding personnel officers at the Shin'nippon Seitetsu [Nippon Steel (Yawata Steel, before 1970)]. From this book, the real state of affairs at the time can be known with respect to the 
foreman system and the introduction of job-evaluation-based wages. In addition, Ueda Osamu and Saguchi Kazurō’s Kinrōbumon no Sengoshi (1) - 1950-nendai Ishikawajima Jūkō ni okeru Kinrōseisaku no Tenkai [The Labor History of Post-war Japan (1) - Changes in the labor management policy at the Ishikawajima Heavy Industries during the 1950s] (Discussion Paper, Graduate School of Economics, University of Tokyo, CIRJE-J-193, 2008) explores changes in the labor management policy in the post-war shipbuilding industry on the basis of oral evidence provided by labor management officers at the time. Moreover, in some chapters of Ueda Osamu and Li Jie-sheng's Nihon Tekkōgyō no Keiei Seisan Kanrihōshiki no Keisei to Saihen: Kyōsōryoku no Kōchiku kara Kaigai Tenkai e Higashi Asia tono Hikaku o Shiya ni [The formation and reformation of the management and production systems in the Japanese Steel Industry: From the reinforcement of competitiveness to overseas expansion - A comparison with East Asian counterparts] (Ochanomizu Shobō, 2018), the contents of the interviews are made open as historical records, though it is a book of an academic inquiry.

The Ministry of Health, Labour and Welfare has also implemented oral history studies. Akamatsu Ryōkō Oral History [The oral history of Akamatsu Ryōkō] (C. O. E. Oral Seisaku Kenkyū Project, Seisaku Kenkyū Daigakuin Daigaku [National Graduate Institute for Policy Studies (GRIPS)], 2005) is historical evidence on labor policies. This work includes testimonies regarding the enactment process of the 1985 Equal Employment Opportunity Law.

As for Hisamoto Norio's oral history studies, Yamada Kōji Shi (Moto Sanyō Denki Rōdō Kumiai Iinchō) Oral History [The oral history of Mr. Yamada Kōji (former Chairman of the Sanyō Electric Workers' Union] and Yoshimoto Jinzō Shi Tsujimoto Kenji Shi Oral History [The oral histories of Messrs. Yoshimoto Jinzō and Tsujimoto Kenji] (Working Paper, Graduate School of Economics, University of Kyoto, J-66-67, 2008), the former concerns a company-based trade union and the latter, the establishment of the Kansai Seisansei Honbu [Kansai Productivity Center].

Tosu-shi-shi Kenkyū Hen Dai 5-shū Kiteki no Kioku - Tetsudōin no Oral History [Studies on the history of Tosu City, vol. 5, Memories of steam whistle - Oral histories of railroad workers] (Tosu: Tosu-shi, 2006) edited by Tosu-shi-shi Hensan Iinkai [The Editing Committee of the History of Tosu City] and Nakamura Naofumi is a collection of oral histories regarding rank-and-file railroad workers, though the title does not give an impression that this book is about labor oral history. In addition, Tōhoku Fukushi Daigaku Kyōju Satō Masao Oral History [The oral history of Satō Masao, Professor of the Tōhoku Fukushi University] (Kakenhi Hōkokusho, 2007) edited by Nakamura Naofumi, Mizumachi Yūichirō, Hotta Satoko and Ishida Naoko is another testimony provided by a former employee of the Japan National Railways and leader of a railroad workers' union.

Memoirs of academic researchers should also be added to the list of labor oral histories. Given the wide range of social activities the storytellers were involved in, memoirs such as Arisawa Hiromi's Sengo Keizai o Kataru - Shōwa-shi eno Shōgen [Speaking about the post-war economy - A testimony to the history of Shōwa] (University of Tokyo Press, 1970) and Ōkōchi Kazuo's Shakai Seisaku 40nen - Tsuioku to Iken [40 years with social policies - Recollections and Opinions] (University of Tokyo Press, 1970) are valuable not only as academic thoughts but as historical records.

There are also oral histories which appeared in magazines in the form of serialized articles. The four testimony series that appeared in Economist, a magazine published by the Mainichi Newspaper, can be regarded as a series of oral histories featuring a variety of storytellers, although they have the problem of space limitations deriving from the nature of the media. In what follows are cited the names of the storytellers who were concerned with labor issues. The interviews with Katō Kanjū, Konno Yojirō, Ii Yashirō, Takano Minoru, Nishio Suehiro and Katayama Tetsu are included in Shōwa Keizai- 
shi eno Shōgen Jō Chū Ge [Testimonies to the economic history of the Shōwa period] (Tokyo: Mainichi Shinbunsha, 1965 and 1966) authored and edited by Andō Yoshio. As for Shiga Yoshio, Nakayama Ichirō, Maeda Hajime, Gōshi Kōhei, Katō Kanjū and Katō Shizue, their interviews are included in Gendai-shi o Tsukuru Hitobito 1-4 [People who are making the contemporary history, vols. 1-4] (Tokyo: Mainichi Shinbunsha, 1971 and 1972) edited by Nakamura Takafusa, Itō Takashi and Hara Akira. As for Hara Shigeru, his interview is included in Sengo Sangyō-shi eno Shōgen 1-5 [Testimonies to the post-war industrial history, vols. 1-5] (Tokyo: Mainichi Shinbunsha, 1977 - 1979) edited by the Editorial Department of Economist. As for Komatsu Hiroshi, Gōshi Kōhei, Ebitani Takahiro, Miyata Yoshiji and Satō Yoshio, their interviews are included in Kōdo Keizai Seichō eno Shōgen Jō Ge [Testimonies to the high economic growth, vols. 1 and 2] (Tokyo: Nihon Keizai Hyōronsha, 1999) edited by the Editorial Department of Economist.

Next, a wide variety of oral histories which appeared in university bulletins and other magazines are enumerated below. However, it should be admitted in advance that the list is not complete. If the title of an article does not include the term, "oral history," it cannot be discerned whether or not the article falls within the category of oral history unless checked directly in the magazine. The retrieval of previous oral history studies is an indispensable task which must be continued.

"Nihonteki Kankō o Kizuita Hitotachi - Sono 1-3 [People who established Japanese employment practices, vols. 1-3] (including Kobayashi Hiroshi (the Nippon Steel), Yamamoto Keimei (the Toyota Motor), Tanaka Shin'ichirō (the Jūjō Paper))“ (Nihon Rōdōkenkyū Zasshi [The Japanese Journal of Labour Studies], nos. 275, 276, 277, 280, 281, 282, 289 and 290, 1987 - 1988) by Tanaka Hirohide. "Kaisō: Zensen Dōmei Reimeiki no Koro Jō Ge [Recollections: The early years of the Japanese Federation of Textile Workers' Unions, vols. 1 and 2]" (Nihon Bōseki Geppō [The Japan Cotton Spinners' Association Monthly Report], nos. 534 and 535, 1991) by Takita Minoru. "Sengo no Bōseki ni okeru Rōmukanri Kyōikumondai Jō Ge [Problems in the post-war spinning industry concerning labor management and education]" (Nihon Bōseki Geppō, nos. 553 and 554, 1993) by Kataoka Mamoru. "Sengo Rōdōundō no 'Shinwa' o Minaosu Dai 1-5-kai [Rethinking the myths of the post-war labor movement, 1-5] (including Masuyama Tasuke, Suzuki Ichizō, Takaragi Fumihiko and Sawada Hiroshi)" (Sekai, nos. 657-661, 1999) edited by Sengo Rōdōundō-shi Kenkyūkai [The Research Association for the History of the Post-war Labor Movement]. "Sengo Menbōseki ni okeru Rōmukanri (1) - (5) [The labor management in the post-war cotton spinning industry]" (Osaka Daigaku Keizaigaku [The Osaka University economic review], vol. 51, nos. 1, 2 and 3, 2001; no. 4, 2002; vol.52, no. 1, 2002) by Murakami Yoshiyuki, Abe Takeshi and Higashiguchi Satoshi. "Togawa Yoshio Shi Oral History: Sanson Kōsakutai Sankakeiken o Chūshin ni (1) [The oral history of Mr. Togawa Yoshio: Experiences in the 'Mountain Village Operation Unit' (1)]" and "Togawa Yoshio Shi Kikigaki: Sengo Yamamura Kōsakutai Chūgokugaku (2) [Interviews with Mr. Togawa Yoshio: The post-war period, the 'Mountain Village Operation Unit' and Chinese studies]" (Yokohama Kokuritsu Daigaku Ryūgakusei Center Kyōiku Kenkyū Ronshū [Journal of the International Student Center, Yokohama National University], nos. 14 and 15, 2007 and 2008) by Hasegawa Kenji. "ME Kakumei o Ikita Senbankō no Momogatari - Koseki Tomohiro kara no Kikgaki no Kiroku [A story of a turner who lived through the ME revolution - The record of interviews with Koseki Tomohiro]" (Keizai Shirin [The Hōsei University economic review], vol. 75, nos. 1-4, 2007 - 2008) by Hagiwara Susumu. "General Electric Sha ni okeru Daisotsu Engineer Kyōiku [The engineering education for university graduates at the General Electric]" (Shōgaku Ronshū [The Chūō University journal of commerce], vol. 54. nos. 1 and 2, 2012) by Sekiguchi Teiichi. "Sankanbu Shatakugai no oral history - Shikamori Shataku no Seikatsu no Kioku [Oral histories regarding lives in a residential area amid a mountainous region - Memories of the Shikamori 
Company Houses]" (Nara Kōgyō Kōtō Senmon-gakkō Kenkyū Kiyō [The research bulletin of Nara College, National Institute of Technology], vol. 49, 2014) by Takehara Tomoya. "Shakubetsu Tankō no Heizan to Kodomotachi - Moto Shakubetsu Tankō Chūgakkō Kyōtō Matsumi Hiroshi Shi ni yoru Kōen no Kiroku [The closure of the Shakubetsu coalfield and children - The record of a public lecture by Matsumi Hiroshi, former Vice-principle of the Shakubetsu Tankō Junior High School]" (JAFCOF Kushiro Kenkyūkai Research Paper, vol. 7, 2016) edited by Shimazaki Naoko and Kasahara Ryōta. “Tankō Man kara Gyōsei Man e - Moto Shoro Tankō Rōso Hoan-bushō Sumiya Masaji Shi ni yoru Kōen no Kiroku [From a miner to an administration officer - The record of a public lecture by Sumiya Masaji, former Head of the Security Department, the Shoro Coalminers' Union]" (JAFCOF Kushiro Kenkyūkai Research Paper, vol. 8, 2016) edited by Kasahara Ryōta, Ishikawa Takaori and Shimazaki Naoko. "Hōsō no Oral History 'Hōsō Woman' Shi (3) Okamoto Natsumi San (Moto Nippon Hōsō Kyōkai Rōdō Kumiai Shokichō) - 'Rōdōsha to Josei no Shiten de Mitsumeta Hōsōkai [The oral history of the broadcasting industry: The history of female broadcasters (3) Ms. Okamoto Natsumi (former Chief Secretary of the NHK Employees' Union) - The legal circles seen from the standpoint of a worker and woman]" (Hōsō Kenkyū to Chōsa [Broadcasting Studies], 67 (6), 2017) by Hirotani Kyōko.

\section{Oral History Projects in which the Author Participated}

The first oral history project the author was involved in was the C.O.E. Seisaku Kenkyū Project's "Oral Method ni yoru Seisaku Kenkyū no Kisoteki Kenkyū [Basic studies on policies through the oral method] (2000 - 2004)" organized by the National Graduate Institute for Policy Studies (GRIPS). It was a five-year project based on the oral history research tradition built in the field of politics, and the author took part in its economic and labor history section. The project conducted twelve hundred interviews with a little less than a hundred and eighty people for about twenty-four hundred hours. As for the details of this largest post-war oral history project, see Oral Method ni yoru Seisaku no Kisokenkyū (Kenkyū Seika Hōkokusho) [Basic studies on policies through the oral method (Report of research results)] (Tokyo: GRIPS, 2005) edited by Itō Takashi.

The oral history method adopted by the GRIPS project was established by Mikuriya Takashi, Representative of this project (Mikuriya 2002, 2007 and 2019). One of the characteristics of the method is to put all the spoken words into written words and publish the whole interview in the form of a booklet after being corrected and sanctioned by the storyteller. This publication style requires a lot of effort and money. Thanks to this method, however, source criticism has been made possible, and oral history, which has hitherto been used only complementarily, has now become a shared tool of historians. Inheriting this method, the author has planned and participated in many oral history projects.

Although labor oral history studies can be sorted out by project, this article classifies them by research subject (See Table 1). For, otherwise, it would be difficult for readers to grasp the whole picture due to the large number of projects the author took part in, which sometimes even overlapped. Incidentally, the author did not attend all the interviews listed. In some cases, therefore, other researchers conducted interviews. In the list are specified not only the storytellers but also the interviewers. 388 interviews have been conducted in the projects cited in the list. Although a growing number of researchers are making use of these interviews, it is a future task to increase the number of such researchers much further.

Table 1: Oral History Projects in which the Author Participated

\begin{tabular}{|c|c|c|}
\hline Oral History & Interviewee's Position & Interviewer \\
\hline 1. Oral Histories regarding Trade Unions in the Machinery and Metal Industries \\
\hline
\end{tabular}




\begin{tabular}{|c|c|c|}
\hline $\begin{array}{l}\text { Amaike, Seiji. Rōdōundō no } \\
\text { Shōgen [Testimonies regarding the } \\
\text { labor movement] (twelve } \\
\text { interviews). Tokyo: Nihon } \\
\text { Rōdōkaikan (incorporated } \\
\text { foundation), 2002. }\end{array}$ & $\begin{array}{l}\text { Former Kaichō [Chairman] of the } \\
\text { Dōmei [Japan Confederation of } \\
\text { Labor]. Former Kaichō of the } \\
\text { Zenkin Dōmei [Japan Federation of } \\
\text { Metal Workers' Unions] }\end{array}$ & $\begin{array}{l}\text { Itō, Takashi. Kurosawa, Hiromichi. } \\
\text { Umezaki, Osamu. }\end{array}$ \\
\hline $\begin{array}{l}\text { Hayashi, Fujio. Honto no Jibun o } \\
\text { Ikiru [Living my true self]. Tokyo: } \\
\text { Seishi Shuppan, } 2004 .\end{array}$ & \multirow[t]{2}{*}{$\begin{array}{l}\text { Former Kaichō of the Tokyo Dōmei } \\
\text { [Japan Confederation of Labour, } \\
\text { Tokyo] }\end{array}$} & \multirow[t]{2}{*}{$\begin{array}{l}\text { Umezaki, Osamu. Nagumo, Chiaki } \\
\text { Shimanishi, Tomoki. }\end{array}$} \\
\hline $\begin{array}{l}\text { Hayashi Fujio Oral History (nine } \\
\text { interviews). Tokyo: Keio } \\
\text { University Press, } 2008 .\end{array}$ & & \\
\hline $\begin{array}{l}\text { Tokyo Kinzoku Tōitsu Rōdōkyōyaku } \\
\text { Oral History [Oral Histories } \\
\text { regarding the Tokyo Metal } \\
\text { Workers' Unified Labor } \\
\text { Agreement] (six interviews). } \\
\text { Tokyo: Keiō Gijuku Daigaku } \\
\text { Sangyō Kenkyūsho [Keio } \\
\text { Economic Observatory], } 2007 .\end{array}$ & $\begin{array}{l}\text { Former leaders of the Zenkin } \\
\text { Dōmei. Employers of machinery } \\
\text { and metal companies. }\end{array}$ & $\begin{array}{l}\text { Umezaki, Osamu. Nagumo, Chiaki. } \\
\text { Shimanishi, Tomoki. }\end{array}$ \\
\hline $\begin{array}{l}\text { Hirasawa Eiichi Oral History (five } \\
\text { interviews). } 2012 .\end{array}$ & $\begin{array}{l}\text { Leader of the Zenkoku Kinzoku } \\
\text { Kumiai [National Federation of } \\
\text { Metal and Engineering Workers' } \\
\text { Unions] }\end{array}$ & $\begin{array}{l}\text { Umezaki, Osamu. Nagumo, Chiaki. } \\
\text { Shimanishi, Tomoki. }\end{array}$ \\
\hline $\begin{array}{l}\text { Ishihara Toshiaki Oral History } \\
\text { (two interviews). Kakenhi } \\
\text { Hōkokusho [The Grants-in-aid for } \\
\text { Scientific Research Report], } 2015 .\end{array}$ & $\begin{array}{l}\text { Former Kaichō of the Rengō Osaka } \\
\text { [Japanese Trade Union } \\
\text { Confederation, Osaka], former } \\
\text { Iinchō [Chairman] of the Zenkin } \\
\text { Dōmei Osaka }\end{array}$ & $\begin{array}{l}\text { Umezaki, Osamu. Nagumo, Chiaki. } \\
\text { Shimanishi, Tomoki. }\end{array}$ \\
\hline $\begin{array}{l}\text { "<Shiryō Shōkai [Historical } \\
\text { record] }>\text { Sōhyō Zenkin Sumitomo } \\
\text { Jūkikai Kōgyō Shibu no Katsudō to } \\
\text { Kumiai Bunretsu [Activities and } \\
\text { the break-up of the Sumitomo } \\
\text { Heavy Industries Branch of the } \\
\text { National Federation of Metal and } \\
\text { Engineering Workers' Unions, the } \\
\text { General Council of Trade Unions] } \\
\text { (one interview)." 2013. }\end{array}$ & $\begin{array}{l}\text { Former leaders of the Sumitomo } \\
\text { Heavy Industries Workers' Union }\end{array}$ & Umezaki, Osamu. Nagumo, Chiaki. \\
\hline $\begin{array}{l}\text { "<Shiryō Shōkai [Historical } \\
\text { record]> Sōhyō Zenkin Sumitomo } \\
\text { Jūkikai Kōgyō Shibu no Katsudō to } \\
\text { Kumiai Bunretsu (2) [Activities and } \\
\text { the break-up of the Sumitomo } \\
\text { Heavy Industries Branch of the } \\
\text { National Federation of Metal and } \\
\text { Engineering Workers' Unions, the } \\
\text { General Council of Trade Unions, } \\
\text { (2)] (one interview)." 2014. }\end{array}$ & $\begin{array}{l}\text { Former leaders of the Sumitomo } \\
\text { Heavy Industries Workers' Union }\end{array}$ & Umezaki, Osamu. Nagumo, Chiaki. \\
\hline
\end{tabular}




\begin{tabular}{|c|c|c|}
\hline \multicolumn{3}{|c|}{ 2. Oral Histories regarding Industrial Relations in the Electrical Industry } \\
\hline $\begin{array}{l}\text { Takahata Keiichi Oral History } \\
\text { (seven interviews). Tokyo: GRIPS, } \\
2004 .\end{array}$ & $\begin{array}{l}\text { Iinchō of the Matsushita Denki } \\
\text { Rōren [Matsushita Electric Branch } \\
\text { of the All-Japan Federation of } \\
\text { Electric Machine Workers' Unions] }\end{array}$ & $\begin{array}{l}\text { Inoki, Takenori. Kamuro, Ayami. } \\
\text { Iwata, Kenji. Umezaki, Osamu. }\end{array}$ \\
\hline $\begin{array}{l}\text { Kashiyama, Toshifumi. Enkō Kinkō } \\
\text { [Attack nearby enemies while } \\
\text { befriending remote ones] (twelve } \\
\text { interviews). Hiratsuka: Tōkai } \\
\text { University Press, 2006. }\end{array}$ & $\begin{array}{l}\text { Former Kaichō of the Minkan } \\
\text { Rengō [All-Japan Council of } \\
\text { Private Sector Trade Unions] }\end{array}$ & $\begin{array}{l}\text { Umezaki, Osamu. Nagumo, Chiaki. } \\
\text { Shimanishi, Tomoki. }\end{array}$ \\
\hline $\begin{array}{l}\text { Warashina Mitsuharu Oral History } \\
\text { (four interviews). Kakenhi } \\
\text { Hōkokusho, } 2014 .\end{array}$ & Former Iinchō of the Denki Rōren & $\begin{array}{l}\text { Umezaki, Osamu. Nagumo, Chiaki. } \\
\text { Shimanishi, Tomoki. }\end{array}$ \\
\hline $\begin{array}{l}\text { Sakioka Toshikatsu Oral History } \\
\text { (four interviews). Kakenhi } \\
\text { Hōkokusho, } 2013 .\end{array}$ & $\begin{array}{l}\text { Former leader of the Denki Rengō } \\
\text { Kumiai [Japanese Electrical, } \\
\text { Electronic \& Information Union] }\end{array}$ & Taguchi, Kazuo. Suzuki, Makoto. \\
\hline $\begin{array}{l}\text { Katō Noboru Oral History (five } \\
\text { interviews). Kakenhi Hōkokusho, } \\
\text { 2014. }\end{array}$ & $\begin{array}{l}\text { Former leader of the Denki Rengō } \\
\text { Kumiai }\end{array}$ & Taguchi, Kazuo \\
\hline $\begin{array}{l}\text { Yoshimura Toshio Oral History } \\
\text { (four interviews). Kakenhi } \\
\text { Hōkokusho, 2015. }\end{array}$ & $\begin{array}{l}\text { Former leader of the Mitsubishi } \\
\text { Electric Workers' Union }\end{array}$ & Suzuki, Makoto \\
\hline $\begin{array}{l}\text { Kuno Osamu Oral History (two } \\
\text { interviews). Kakenhi Hōkokusho, } \\
2013 .\end{array}$ & $\begin{array}{l}\text { Former leader of the Mitsubishi } \\
\text { Electric Workers' Union }\end{array}$ & Suzuki, Makoto \\
\hline $\begin{array}{l}\text { Umehara Shirō Oral History (four } \\
\text { interviews). Kakenhi Hōkokusho, } \\
2014 .\end{array}$ & $\begin{array}{l}\text { Former personnel officer at the } \\
\text { Tōshiba Electric }\end{array}$ & Taguchi, Kazuo. Suzuki, Makoto. \\
\hline \multicolumn{3}{|c|}{$\begin{array}{l}\text { 3. Oral Histories regarding the Zensen Dōmei [Japanese Federation of Textile Workers' Unions] (present- } \\
\text { day the UA Zensen [Japanese Federation of Textile, Chemical, Food, Commercial, Service and General } \\
\text { Workers' Unions]) }\end{array}$} \\
\hline $\begin{array}{l}\text { Usami, Tadanobu. Kokorozashi ni } \\
\text { Ikiru [Living with determination] } \\
\text { (nine interviews). Gotenba: Fuji } \\
\text { Shakaikyōiku Center, } 2003 .\end{array}$ & $\begin{array}{l}\text { Former Kaichō [Chairman] of the } \\
\text { Dōmei [Japan Confederation of } \\
\text { Labour]. Former Kaichō of the } \\
\text { Zensen Dōmei. }\end{array}$ & $\begin{array}{l}\text { Itō, Takashi. Kurosawa, Hiromichi. } \\
\text { Umezaki, Osamu. }\end{array}$ \\
\hline $\begin{array}{l}\text { Satō Fumio Oral History (ten } \\
\text { interviews). } 2010 .\end{array}$ & Former leader of the Zensen Dōmei & $\begin{array}{l}\text { Umezaki, Osamu. Nagumo, Chiaki. } \\
\text { Shimanishi, Tomoki. }\end{array}$ \\
\hline $\begin{array}{l}\text { Wada Tadashi Oral History (five } \\
\text { interviews). } 2011 .\end{array}$ & Former leader of the Zensen Dōmei & $\begin{array}{l}\text { Umezaki, Osamu. Nagumo, Chiaki. } \\
\text { Shimanishi, Tomoki. }\end{array}$ \\
\hline $\begin{array}{l}\text { Ninomiya Makoto Oral History (six } \\
\text { interviews). } 2012 .\end{array}$ & Former leader of the Zensen Dōmei & $\begin{array}{l}\text { Umezaki, Osamu. Nagumo, Chiaki. } \\
\text { Shimanishi, Tomoki. }\end{array}$ \\
\hline $\begin{array}{l}\text { Ninomiya Makoto Oral History, } \\
\text { Dai 2-kan [Vol. 2] (four } \\
\text { interviews). Tōkai Gakuen Daigaku } \\
\text { Tokubetsu (Sinsei) Hōkokusho } \\
\text { [Tōkai Gakuen University special } \\
\text { (application) report], 2012. }\end{array}$ & Former leader of the Zensen Dōmei & $\begin{array}{l}\text { Umezaki, Osamu. Nagumo, Chiaki. } \\
\text { Shimanishi, Tomoki. }\end{array}$ \\
\hline
\end{tabular}




\begin{tabular}{|c|c|c|}
\hline $\begin{array}{l}\text { Noguchi Naoya Oral History (five } \\
\text { interviews). Tōkai Gakuen Daigaku } \\
\text { Tokubetsu (Sinsei) Kenkyūhi } \\
\text { Hōkokusho [Tōkai Gakuen } \\
\text { University special (application) } \\
\text { research expenses report], 2017. }\end{array}$ & Former leader of the Zensen Dōmei & $\begin{array}{l}\text { Umezaki, Osamu. Nagumo, Chiaki. } \\
\text { Shimanishi, Tomoki. }\end{array}$ \\
\hline $\begin{array}{l}\text { Sugai Yoshio Oral History (five } \\
\text { interviews). Kakenhi Hōkokusho, } \\
2014 .\end{array}$ & Former leader of the Zensen Dōmei & $\begin{array}{l}\text { Nagumo, Chiaki. Shimanishi, } \\
\text { Tomoki. }\end{array}$ \\
\hline $\begin{array}{l}\text { Ochiai Kiyoshi Oral History (four } \\
\text { interviews). Kakenhi Hōkokusho, } \\
2018 .\end{array}$ & Former leader of the Zensen Dōmei & $\begin{array}{l}\text { Umezaki, Osamu. Nagumo, Chiaki. } \\
\text { Shimanishi, Tomoki. }\end{array}$ \\
\hline $\begin{array}{l}\text { Tokuda Kōzō Oral History (five } \\
\text { interviews). Kakenhi Hōkokusho, } \\
\text { 2018. }\end{array}$ & Former leader of the Zensen Dōmei & $\begin{array}{l}\text { Umezaki, Osamu. Nagumo, Chiaki. } \\
\text { Shimanishi, Tomoki. }\end{array}$ \\
\hline $\begin{array}{l}\text { Umezaki, Osamu, Chiaki Nagumo } \\
\text { and Tomoki Shimanishi. } \\
\text { "Yamanaka Yōsuke Shi Oral } \\
\text { History [The oral history of Mr. } \\
\text { Yōsuke Yamanaka] (one } \\
\text { interview)." Shōgai Gakushū to } \\
\text { Career Design [Lifelong learning } \\
\text { and career design], vol. 16, no. 2, } \\
2019 .\end{array}$ & Former leader of the Zensen Dōmei & $\begin{array}{l}\text { Umezaki, Osamu. Nagumo, Chiaki. } \\
\text { Shimanishi, Tomoki. }\end{array}$ \\
\hline $\begin{array}{l}\text { Ömi Kenshi Jinkensōgi Oral } \\
\text { History (1) [The oral history } \\
\text { regarding the Ōmi Kenshi Human } \\
\text { Rights Dispute (1)] (three } \\
\text { interviews). Kakenhi Hōkokusho, } \\
2013 .\end{array}$ & $\begin{array}{l}\text { Former member of the Ōmi Kenshi } \\
\text { Rōdō Kumiai [Ōmi Kenshi } \\
\text { Workers' Union] }\end{array}$ & $\begin{array}{l}\text { Umezaki, Osamu. Nagumo, Chiaki. } \\
\text { Shimanishi, Tomoki. }\end{array}$ \\
\hline $\begin{array}{l}\text { Ōmi Kenshi Jinkensōgi Oral } \\
\text { History (2) Nakamura, Yukio Oral } \\
\text { History (two interviews). Kakenhi } \\
\text { Hōkokusho, 2014. }\end{array}$ & $\begin{array}{l}\text { Former member of the Ōmi Kenshi } \\
\text { Rōdō Kumiai [Ōmi Kenshi } \\
\text { Workers' Union] }\end{array}$ & $\begin{array}{l}\text { Umezaki, Osamu. Nagumo, Chiaki. } \\
\text { Shimanishi, Tomoki. }\end{array}$ \\
\hline $\begin{array}{l}\text { Ōmi Kenshi Jinkensōgi Oral } \\
\text { History (3) Asakura, Katsumi Oral } \\
\text { History (three interviews). Kakenhi } \\
\text { Hōkokusho, } 2017 .\end{array}$ & $\begin{array}{l}\text { Former member of the Ōmi Kenshi } \\
\text { Rōdō Kumiai [Ōmi Kenshi } \\
\text { Workers' Union] }\end{array}$ & $\begin{array}{l}\text { Umezaki, Osamu. Nagumo, Chiaki. } \\
\text { Shimanishi, Tomoki. }\end{array}$ \\
\hline \multicolumn{3}{|c|}{ 4. Oral Histories regarding Industrial Relations in the Steel Industry } \\
\hline $\begin{array}{l}\text { Miyata Yoshiji Oral History (nine } \\
\text { interviews). Tokyo: GRIPS, } 2003 .\end{array}$ & $\begin{array}{l}\text { Former Kaichō of the IMJC. } \\
\text { Former Iinchō of the Tekkō Rōren } \\
\text { [Japan Federation of Steel Workers' } \\
\text { Unions]. }\end{array}$ & $\begin{array}{l}\text { Inoki, Takenori. Kurosawa, } \\
\text { Hiromichi. Umezaki, Osamu. }\end{array}$ \\
\hline $\begin{array}{l}\text { Okuda Kenji Oral History (eleven } \\
\text { interviews). Tokyo: GRIPS, } 2004 .\end{array}$ & $\begin{array}{l}\text { Former personnel officer at the } \\
\text { Nippon Kōkan (NKK) }\end{array}$ & $\begin{array}{l}\text { Odaka Kōnosuke. Umezaki, } \\
\text { Osamu. Hashino, Tomoko. }\end{array}$ \\
\hline $\begin{array}{l}\text { Gotō Tatsuo Oral history (ten } \\
\text { interviews). Tokyo: GRIPS, } 2004 .\end{array}$ & $\begin{array}{l}\text { Former leader of the Nippon Kōkan } \\
\text { Kumiai [Nippon Kōkan Workers' } \\
\text { Union] }\end{array}$ & $\begin{array}{l}\text { Odaka Kōnosuke. Umezaki, } \\
\text { Osamu. Hashino, Tomoko. Inoue, } \\
\text { Masao. Aoki, Hiroyuki. }\end{array}$ \\
\hline
\end{tabular}




\begin{tabular}{|c|c|c|}
\hline $\begin{array}{l}\text { Kunimoto Minoru Oral History } \\
\text { (two interviews). Tokyo: GRIPS, } \\
2004 .\end{array}$ & $\begin{array}{l}\text { Former leader of the Nippon Kōkan } \\
\text { Kumiai }\end{array}$ & $\begin{array}{l}\text { Odaka Kōnosuke. Umezaki, } \\
\text { Osamu. Aoki, Hiroyuki. }\end{array}$ \\
\hline $\begin{array}{l}\text { Tan'no Shōsuke Oral History (two } \\
\text { interviews). Tokyo: GRIPS, } 2004 .\end{array}$ & $\begin{array}{l}\text { Former leader of the Nippon Kōkan } \\
\text { Kumiai }\end{array}$ & $\begin{array}{l}\text { Odaka Kōnosuke. Umezaki, } \\
\text { Osamu. Aoki, Hiroyuki. }\end{array}$ \\
\hline $\begin{array}{l}\text { Nishikawa Tadashi Oral History } \\
\text { (three interviews). Tokyo: GRIPS, } \\
2005 .\end{array}$ & $\begin{array}{l}\text { Former personnel officer at the } \\
\text { Nippon Kōkan }\end{array}$ & $\begin{array}{l}\text { Odaka Kōnosuke. Umezaki, } \\
\text { Osamu. Aoki, Hiroyuki. }\end{array}$ \\
\hline $\begin{array}{l}\text { Iwasaki Kaoru Oral History (two } \\
\text { interviews). Tokyo: GRIPS, } 2005 .\end{array}$ & $\begin{array}{l}\text { Former leader of the Nippon Kōkan } \\
\text { Kumiai }\end{array}$ & $\begin{array}{l}\text { Odaka Kōnosuke. Umezaki, } \\
\text { Osamu. Aoki, Hiroyuki. }\end{array}$ \\
\hline $\begin{array}{l}\text { Nippon Kōkan Gijutsusha Oral } \\
\text { History [The oral history of } \\
\text { engineers employed by the NKK] } \\
\text { (three interviews). Tokyo: GRIPS, } \\
2005 .\end{array}$ & $\begin{array}{l}\text { Former engineer employed by the } \\
\text { Nippon Kōkan }\end{array}$ & $\begin{array}{l}\text { Odaka Kōnosuke. Umezaki, } \\
\text { Osamu. Aoki, Hiroyuki. }\end{array}$ \\
\hline $\begin{array}{l}\text { Tekkō Rōren Chingin Seisaku Oral } \\
\text { History (Chiba Toshio, Ishizuka } \\
\text { Takurō) [The oral history regarding } \\
\text { the wage policy of the Japan } \\
\text { Federation of Steel Workers' } \\
\text { Unions] (four interviews). Kakenhi } \\
\text { Hōkokusho. }\end{array}$ & Former leader of the Tekkō Rōren & $\begin{array}{l}\text { Umezaki, Osamu. Aoki, Hiroyuki. } \\
\text { Sugiyama, Hiroshi. }\end{array}$ \\
\hline $\begin{array}{l}\text { Tekkō Sangyō Rōshikankei Oral } \\
\text { History [The oral history regarding } \\
\text { industrial relations in the steel } \\
\text { industry] (three interviews). } \\
\text { Kakenhi Hōkokusho, 2008. }\end{array}$ & $\begin{array}{l}\text { Former personnel officers of steel } \\
\text { companies. Former leaders of trade } \\
\text { unions. }\end{array}$ & $\begin{array}{l}\text { Umezaki, Osamu. Sugiyama, } \\
\text { Hiroshi. }\end{array}$ \\
\hline $\begin{array}{l}\text { Gekidōki no Rōshikankei - } \\
\text { Kamaishi Seitetsusho Rōsei Rōso } \\
\text { no Oral History [Industrial } \\
\text { relations in tempestuous times - } \\
\text { The oral history regarding labor } \\
\text { management and the trade union at } \\
\text { the Kamaishi Steel Works] (five } \\
\text { interviews). Tokyo: Tokyo Daigaku } \\
\text { Shakaikagaku Kenkyūsho [Institute } \\
\text { of Social Science, University of } \\
\text { Tokyo], 2010. }\end{array}$ & $\begin{array}{l}\text { Personnel officers and shop floor } \\
\text { workers at the Kamaishi Steel } \\
\text { Works }\end{array}$ & $\begin{array}{l}\text { Nakamura, Naofumi. Nita, Michio. } \\
\text { Umezaki, Osamu. Aoki, Hiroyuki. }\end{array}$ \\
\hline $\begin{array}{l}\text { Honō no Kioku I - Seisen, Seikō, } \\
\text { Tōkai Tenshutsusha Hen } \\
\text { [Memories of fire } 1 \text { - About pig } \\
\text { iron making, steel making and } \\
\text { workers transferred to the Tōkai } \\
\text { region] (six interviews). Tokyo: } \\
\text { Tokyo Daigaku Shakaikagaku } \\
\text { Kenkyūsho, 2011. }\end{array}$ & $\begin{array}{l}\text { Personnel officers and shop floor } \\
\text { workers at the Kamaishi Steel } \\
\text { Works }\end{array}$ & $\begin{array}{l}\text { Nakamura, Naofumi. Nita, Michio. } \\
\text { Umezaki, Osamu. Aoki, Hiroyuki. }\end{array}$ \\
\hline
\end{tabular}




\begin{tabular}{|c|c|c|}
\hline $\begin{array}{l}\text { Honō no Kioku: Kamaishi } \\
\text { Seitetsusho Rōdōsha no Oral } \\
\text { History II - Atsuen, Setsubi Hen } \\
\text { [Memories of fire: The oral history } \\
\text { of workers at the Kamaishi Steel } \\
\text { Works } 2 \text { - About rolling and } \\
\text { facilities] (six interviews). Tokyo: } \\
\text { Tokyo Daigaku Shakaikagaku } \\
\text { Kenkyūsho, } 2010 .\end{array}$ & $\begin{array}{l}\text { Personnel officers and shop floor } \\
\text { workers at the Kamaishi Steel } \\
\text { Works }\end{array}$ & Aoki, Hiroyuki \\
\hline $\begin{array}{l}\text { Genba Kanri no Sekai - Kamaishi } \\
\text { Seitetsusho Gijutsusha no Oral } \\
\text { History [The real state of site } \\
\text { management - The oral history of } \\
\text { engineers employed by the } \\
\text { Kamaishi Steel Works] (seven } \\
\text { interviews). Tokyo: Tokyo Daigaku } \\
\text { Shakaikagaku Kenkyūsho, } 2010 .\end{array}$ & $\begin{array}{l}\text { Engineers employed by the } \\
\text { Kamaishi Steel Works }\end{array}$ & $\begin{array}{l}\text { Nakamura, Naofumi. Nita, Michio. } \\
\text { Umezaki, Osamu. Aoki, Hiroyuki. }\end{array}$ \\
\hline $\begin{array}{l}\text { Oguri Hirotoyo Oral History (two } \\
\text { interviews). Kakenhi Hōkokusho, } \\
2013 .\end{array}$ & Former leader of the Tekkō Rōren & Aoki, Hiroyuki \\
\hline $\begin{array}{l}\text { Serizawa Hisayoshi Oral History } \\
\text { (two interviews). Kakenhi } \\
\text { Hōkokusho, } 2014 .\end{array}$ & Former leader of the Tekkō Rōren & Aoki, Hiroyuki \\
\hline $\begin{array}{l}\text { Yokoyama Susumu Oral History } \\
\text { (two interviews). Kakenhi } \\
\text { Hōkokusho, } 2014 .\end{array}$ & Former leader of the Tekkō Rōren & Aoki, Hiroyuki \\
\hline $\begin{array}{l}\text { Tetsuzukuri o Sasae Shinten Saseru } \\
\text { Gijutsusha [Engineers who support } \\
\text { and develop iron making] (Kōchi } \\
\text { Tanki Daigaku Kenkyūsōsho } 2 \\
\text { [Kōchi Junior College Research } \\
\text { Series, 2] ) (three interviews), } 2013 .\end{array}$ & $\begin{array}{l}\text { Engineers working in the steel } \\
\text { industry }\end{array}$ & Aoki, Hiroyuki \\
\hline \multicolumn{3}{|c|}{ 5. Oral Histories of Trade Unions in the Shipbuilding Industry } \\
\hline $\begin{array}{l}\text { Itō Sukesada Oral History (eight } \\
\text { interviews). Tokyo: Keio Economic } \\
\text { Observatory, } 2006 .\end{array}$ & $\begin{array}{l}\text { Former Iinchō of the Zōsen Jūki } \\
\text { Rōren [Japan Federation of } \\
\text { Shipbuilding and Heavy Industries } \\
\text { Workers' Unions] }\end{array}$ & Umezaki, Osamu. Nagumo, Chiaki. \\
\hline $\begin{array}{l}\text { Kanasugi Hidenobu Oral History } \\
\text { (ten interviews). Tokyo: GRIPS, } \\
2004 .\end{array}$ & $\begin{array}{l}\text { Former Iinchō of the Zōsen Jūki } \\
\text { Rōren }\end{array}$ & $\begin{array}{l}\text { Itō, Takashi. Kurosawa, Hiromichi. } \\
\text { Umezaki, Osamu. Nagumo, Chiaki. }\end{array}$ \\
\hline \multicolumn{3}{|c|}{ 6. Oral Histories concerning the Productivity Movement } \\
\hline $\begin{array}{l}\text { Seisansei Undō Oral History } \\
<\text { Rōdō-bu Hen }>\text { [The oral history } \\
\text { concerning the Productivity } \\
\text { Movement: Labor Department], } \\
\text { vol. 1-3, (seventeen interviews). } \\
\text { Tokyo: GRIPS, 2003. }\end{array}$ & $\begin{array}{l}\text { Former employees at Rōdō-bu } \\
\text { [Labor Department], the Nihon } \\
\text { Seisansei Honbu [Japan } \\
\text { Productivity Center] }\end{array}$ & $\begin{array}{l}\text { Umezaki, Osamu. Fujimura, } \\
\text { Hiroyuki. Ishida Mitsuo. }\end{array}$ \\
\hline
\end{tabular}




\begin{tabular}{|c|c|c|}
\hline $\begin{array}{l}\text { Seisansei Undō Oral History } \\
<\text { Kokusai-bu Hen }>\text { [The oral } \\
\text { history concerning the Productivity } \\
\text { Movement: International } \\
\text { Department], vol. } 1 \text { and 2, (fourteen } \\
\text { interviews). Tokyo: GRIPS, } 2003 \text {. }\end{array}$ & $\begin{array}{l}\text { Former employees at Kokusai-bu } \\
\text { [International Department], the } \\
\text { Nihon Seisansei Honbu }\end{array}$ & $\begin{array}{l}\text { Umezaki, Osamu. Mori, Naoko. } \\
\text { Shibata, Hiromichi. }\end{array}$ \\
\hline $\begin{array}{l}\text { Seisansei Undō Oral History } \\
<\text { Keiei Kaihatsu-bu Hen }>\text { [The } \\
\text { oral history concerning the } \\
\text { Productivity Movement: } \\
\text { Management Development } \\
\text { Department] (five interviews). } \\
\text { Tokyo: GRIPS, 2005. }\end{array}$ & $\begin{array}{l}\text { Former employees at Keiei- } \\
\text { Kaihatsu-bu [Management and } \\
\text { Development Department], the } \\
\text { Nihon Seisansei Honbu }\end{array}$ & $\begin{array}{l}\text { Umezaki, Osamu. Mori, Naoko. } \\
\text { Shimanishi, Tomoki. }\end{array}$ \\
\hline $\begin{array}{l}\text { Seisansei Undō Oral History } \\
<\text { Rōdō Shisatsudan Hen }>\text { [The oral } \\
\text { history concerning the Productivity } \\
\text { Movement: The Labor Inspection } \\
\text { Parties] (four interviews). Kakenhi } \\
\text { Hōkokusho, 2006. }\end{array}$ & $\begin{array}{l}\text { The Nihon Seisansei Honbu's } \\
\text { employees who participated in } \\
\text { overseas inspections }\end{array}$ & $\begin{array}{l}\text { Umezaki, Osamu. Mori, Naoko. } \\
\text { Shimanishi, Tomoki. Toda, } \\
\text { Yumiko. }\end{array}$ \\
\hline $\begin{array}{l}\text { Murasugi Yasuo Oral History (one } \\
\text { interview). Tokyo: GRIPS, } 2003 .\end{array}$ & $\begin{array}{l}\text { Former leader of the Ajinomoto } \\
\text { Workers' Union }\end{array}$ & $\begin{array}{l}\text { Umezaki, Osamu. Fujimura, } \\
\text { Hiroyuki. }\end{array}$ \\
\hline $\begin{array}{l}\text { "Seisansei Undō no Oral History - } \\
\text { Kawanabe Iwao Shi (Moto Rōdō- } \\
\text { bu Shokuin) no Shigoto [The oral } \\
\text { history concerning the Productivity } \\
\text { Movement - The work of Mr. Iwao } \\
\text { Kawanabe (former employee at } \\
\text { Labor Depertment] (one } \\
\text { interview)." Shōgai Kyōiku Shakai } \\
\text { to Career Design [Society of } \\
\text { Lifelong learning and Career } \\
\text { Design], no. 1, 2003. }\end{array}$ & $\begin{array}{l}\text { Former employees at Rōdō-bu, the } \\
\text { Nihon Seisansei Honbu }\end{array}$ & Umezaki, Osamu \\
\hline $\begin{array}{l}\text { "Seisansei Undō no Oral History - } \\
\text { Maeda Akio Shi to Nakajō } \\
\text { Kuramitsu Shi no Shigoto [The oral } \\
\text { history concerning the Productivity } \\
\text { Movement - The work of Messrs. } \\
\text { Akio Maeda and Kuramitsu } \\
\text { Nakajō] (one interview)." Hōsei } \\
\text { Daigaku Career Design Gakubu } \\
\text { Kiyō [Bulletin of Career Design } \\
\text { Department, Hōsei University], no. } \\
\text { 2, } 2005 .\end{array}$ & $\begin{array}{l}\text { Former employees at Rōdō-bu, the } \\
\text { Nihon Seisansei Honbu }\end{array}$ & Umezaki, Osamu \\
\hline
\end{tabular}




\begin{tabular}{|c|c|c|}
\hline $\begin{array}{l}\text { "Sengo Nihon no Kigyōka to } \\
\text { Seisansei Undō - Ushio Jirō Shi } \\
\text { (Ushio Denki (Kabu) Kaichō) no } \\
\text { Oral History (Jō) (Ge) [The } \\
\text { industrialization in post-war Japan } \\
\text { and the Productivity Movement - } \\
\text { The Oral History of Mr. Jirō Ushio } \\
\text { (President of the Ushio Electric, } \\
\text { Inc.) Part } 1 \text { and Part 2] (two } \\
\text { interviews)." Mita Shōgaku Kenkȳu } \\
\text { [Mita Business Review], vol. 50, } \\
\text { nos. } 1 \text { and 2, 2007. }\end{array}$ & $\begin{array}{l}\text { Kaichō [President] of the Ushio } \\
\text { Electric, Inc. }\end{array}$ & $\begin{array}{l}\text { Umezaki, Osamu. Mori, Naoko. } \\
\text { Shimanishi, Tomoki. Toda, } \\
\text { Yumiko. }\end{array}$ \\
\hline $\begin{array}{l}\text { "Kigyōka no Kaigai Shisatsu } \\
\text { Taiken: Shiokawa Seijūrō Shi no } \\
\text { Oral History [Entrepreneurs' } \\
\text { experiences of overseas } \\
\text { inspections: The oral history of Mr. } \\
\text { Seijūrō Shiokawa] (one interview)." } \\
\text { Rikkyō Keizaigaku Kenkyū [Rikkyō } \\
\text { Economic Review], vol. 61, no. 2, } \\
2007 .\end{array}$ & $\begin{array}{l}\text { Former Minister of Finance. } \\
\text { Former member of the House of } \\
\text { Representatives. }\end{array}$ & $\begin{array}{l}\text { Umezaki, Osamu. Mori, Naoko. } \\
\text { Shimanishi, Tomoki. }\end{array}$ \\
\hline \multicolumn{3}{|c|}{ 7. Oral Histories regarding Labor Management } \\
\hline $\begin{array}{l}\text { Hyōdō Tsutae Oral History (nine } \\
\text { interviews). Tokyo: GRIPS, } 2003 .\end{array}$ & $\begin{array}{l}\text { Former personnel officer at the } \\
\text { Sumitomo Jūkikai Kōgyō } \\
\text { [Sumitomo Heavy Industries] }\end{array}$ & $\begin{array}{l}\text { Fujimura, Hiroyuki. Umezaki, } \\
\text { Osamu. Nagumo, Chiaki. }\end{array}$ \\
\hline $\begin{array}{l}\text { Kusuda Kyū Oral History (eight } \\
\text { interviews). Tokyo: GRIPS. }\end{array}$ & Wage consultant & Ishida, Mitsuo. Umezaki, Osamu. \\
\hline $\begin{array}{l}\text { Shōkunō Shikaku Seido to Shokunō- } \\
\text { ky } \bar{u}^{\prime} \text { Oral History [The Oral History } \\
\text { concernig the ability-based grading } \\
\text { system and job-evaluation-based } \\
\text { wages] (four interviews). Kakenhi } \\
\text { Hōkokusho, } 2007 .\end{array}$ & Former personnel officers & Umezaki, Osamu \\
\hline $\begin{array}{l}\text { Nōryokushugi Kanri 40-nen- } \\
\text { Nikkeiren Nōryokushugi Kanri Oral } \\
\text { History Kenkyūkai Hōkokusho [40 } \\
\text { years of performance-based human } \\
\text { resource management - The report } \\
\text { of the oral history workshop on the } \\
\text { Japan Federation of Employers' } \\
\text { Associations' performance-based } \\
\text { human resource management] } \\
\text { (eight interviews). Tokyo: Keio } \\
\text { Economic Observatory, 2007. }\end{array}$ & $\begin{array}{l}\text { Members and officers of the } \\
\text { Nikkeiren [Japan Federation of } \\
\text { Employers' Associations] }\end{array}$ & $\begin{array}{l}\text { Yashiro, Atsushi. Seike, Atsuhi. } \\
\text { Ushijima, Toshiaki. Ebisuno, } \\
\text { Sumiko. Umezaki, Osamu. } \\
\text { Nagumo, Chiaki. Shimanishi, } \\
\text { Tomoki. }\end{array}$ \\
\hline
\end{tabular}




\begin{tabular}{|c|c|c|}
\hline $\begin{array}{l}\text { Nihon Keieisha Dantai Renmei to } \\
\text { Sengo no Rōmukanri (1) - } \\
\text { Nikkeiren 50-nen to Shokumu } \\
\text { Bunseki Center o Chüshin ni [The } \\
\text { Japan Federation of Employers' } \\
\text { Associations and the post-war labor } \\
\text { management (1) - The 50-year } \\
\text { history of the Japan Federation of } \\
\text { Employers' Associations and the } \\
\text { Center for Work Analysis] (three } \\
\text { interviews). Tokyo: Keio Economic } \\
\text { Observatory, 2011. }\end{array}$ & Officers of the Nikkeiren & $\begin{array}{l}\text { Yashiro, Atsushi. Ushijima, } \\
\text { Toshiaki. Umezaki, Osamu. } \\
\text { Nagumo, Chiaki. Shimanishi, } \\
\text { Tomoki. }\end{array}$ \\
\hline $\begin{array}{l}\text { Nihon Keieisha Dantai Renmei to } \\
\text { Sengo no Rōmukanri (2) Shinjidai } \\
\text { no 'Nihon teki Keiei' [The Japan } \\
\text { Federation of Employers' } \\
\text { Associations and the post-war labor } \\
\text { management (2) - The 'Japanese- } \\
\text { style management' in a new era] } \\
\text { (six interviews). Tokyo: Keio } \\
\text { Economic Observatory, 2013. }\end{array}$ & Officers of the Nikkeiren & $\begin{array}{l}\text { Yashiro, Atsushi. Ushijima, } \\
\text { Toshiaki. Umezaki, Osamu. } \\
\text { Nagumo, Chiaki. Shimanishi, } \\
\text { Tomoki. }\end{array}$ \\
\hline $\begin{array}{l}\text { Nissan=Renault Alliance to Koyo } \\
\text { Roshi Kankei [The Nissan=Renault } \\
\text { alliance and the industrial relations] } \\
\text { (eight interviews). Tokyo: Keio } \\
\text { Economic Observatory, } 2019 .\end{array}$ & $\begin{array}{l}\text { Former and present executives of } \\
\text { the Nissan Motor. The Nissan } \\
\text { Motor Workers' Union. }\end{array}$ & $\begin{array}{l}\text { Yashiro, Atsushi. Ushijima, } \\
\text { Toshiaki. Umezaki, Osamu. } \\
\text { Nagumo, Chiaki. Shimanishi, } \\
\text { Tomoki. }\end{array}$ \\
\hline $\begin{array}{l}\text { Sengo Chingin Seidoshi Oral } \\
\text { History [The oral history regarding } \\
\text { the post-war wage system] (four } \\
\text { interviews). Kakenhi Hōkokusho, } \\
2008 \text {. }\end{array}$ & Former personnel officers & $\begin{array}{l}\text { Yashiro, Atsushi. Umezaki, Osamu. } \\
\text { Nagumo, Chiaki. }\end{array}$ \\
\hline $\begin{array}{l}\text { Kagiyama Yoshimitsu Oral History } \\
\text { (two interviews). Kakenhi } \\
\text { Hōkokusho, } 2008 .\end{array}$ & Wage consultant & $\begin{array}{l}\text { Yashiro, Atsushi. Umezaki, Osamu. } \\
\text { Nagumo, Chiaki. }\end{array}$ \\
\hline \multicolumn{3}{|c|}{ 8. Oral Histories regarding Labor History Records } \\
\hline $\begin{array}{l}\text { Rōdōshi Shiryō Oral History [The } \\
\text { oral history regarding labor history } \\
\text { records] (five interviews). Kakenhi } \\
\text { Hōkokusho, } 2008 .\end{array}$ & $\begin{array}{l}\text { Researchers engaged in finding and } \\
\text { preserving labor history records }\end{array}$ & In the form of a research workshop \\
\hline $\begin{array}{l}\text { Rōdōshi Shiryō Kenkyūkai Oral } \\
\text { History II [The oral history } \\
\text { regarding the research workshop on } \\
\text { labor history records II] (six } \\
\text { interviews). Kakenhi } \\
\text { Hōkokusho.2010. }\end{array}$ & $\begin{array}{l}\text { Researchers engaged in finding and } \\
\text { preserving labor history records }\end{array}$ & In the form of a research workshop \\
\hline $\begin{array}{l}\text { Rōdōshi Shiryō Kenkyūkai Oral } \\
\text { History III (three interviews). } \\
\text { Kakenhi Hōkokusho, } 2015 .\end{array}$ & $\begin{array}{l}\text { Researchers engaged in finding and } \\
\text { preserving labor history records }\end{array}$ & In the form of a research workshop \\
\hline
\end{tabular}




\begin{tabular}{|c|c|c|}
\hline $\begin{array}{l}\text { “'Sengo Rōdōkumian Undō no } \\
\text { Shōgen Kenkyūkai' no Rekishi- } \\
\text { Takanashi Akira Shi ni Kiku [The } \\
\text { history of the 'Research } \\
\text { Association for Testimonies } \\
\text { regarding the Post-war Trade Union } \\
\text { Movement' - An interview with } \\
\text { Mr. Akira Takanashi] (one } \\
\text { interview).” Oral History } 6 \text { [The } \\
\text { GRIPS oral history 6], } 2002 .\end{array}$ & $\begin{array}{l}\text { Former Kaichō [President] of the } \\
\text { Nihon Rōdō Kenkyū Kikō [Japan } \\
\text { Institute for Labour Studies] }\end{array}$ & Umezaki, Osamu. Aoki, Hiroyuki. \\
\hline \multicolumn{3}{|c|}{ 9. Other Oral Histories } \\
\hline $\begin{array}{l}\text { Takaragi Fumihiko Oral History } \\
\text { (seventeen interviews). Tokyo: } \\
\text { GRIPS, } 2005 .\end{array}$ & $\begin{array}{l}\text { Former Iinchō of the Zentei [Japan } \\
\text { Postal Workers' Union] }\end{array}$ & $\begin{array}{l}\text { Itō, Takashi. Tezuka, Kazuaki. } \\
\text { Arima, Manabu. Umezaki, Osamu. } \\
\text { Shimanishi, Tomoki. }\end{array}$ \\
\hline $\begin{array}{l}\text { Yamagishi Akira Oral History (ten } \\
\text { interviews). Tokyo: GRIPS, } 2005 .\end{array}$ & $\begin{array}{l}\text { Former Kaichō of the Rengō } \\
\text { [Japanese Trade Union } \\
\text { Confederation] }\end{array}$ & $\begin{array}{l}\text { Itō, Takashi. Umezaki, Osamu. } \\
\text { Nagumo, Chiaki. }\end{array}$ \\
\hline $\begin{array}{l}\text { Zenkoku Ippan Oral History } \\
\text { (Tajima Keiichi, Takahara Takeo) } \\
\text { [The oral history of the National } \\
\text { Union of General Workers (Keiichi } \\
\text { Tajima and Takeo Takahara)] (five } \\
\text { interviews). Kakenhi Hōkokusho, } \\
2015 .\end{array}$ & $\begin{array}{l}\text { Former leaders of the Zenkoku } \\
\text { Ippan [National Union of General } \\
\text { Workers] }\end{array}$ & $\begin{array}{l}\text { Nagumo, Chiaki. Shimanishi, } \\
\text { Tomoki. }\end{array}$ \\
\hline $\begin{array}{l}\text { "Tabuchi Sunao Shi Oral History } \\
(1,2) \text { : Osaka ni okeru Kyōshokuin } \\
\text { Rōdōkumiai Undō [The oral history } \\
\text { of Mr. Sunao Tabuchi: The trade } \\
\text { union movement of teachers in } \\
\text { Osaka }(1,2) \text { ] (two interviews)." } \\
\text { Shōgai Gakushī to Career Design, } \\
\text { vol. 15, no. } 2 \text { and vol. 16, no. 1, } \\
\text { 2018. }\end{array}$ & $\begin{array}{l}\text { Former leader of the Nikkyōso } \\
\text { [Japan Teachers' Union] }\end{array}$ & $\begin{array}{l}\text { Umezaki, Osamu. Nagumo, Chiaki. } \\
\text { Shimanishi, Tomoki. }\end{array}$ \\
\hline $\begin{array}{l}\text { "Kōdo Seichōki ni okeru } \\
\text { Gijutsusha Yōsei no Oral History - } \\
\text { Tachikawa Isamu Shi (Moto Kōgyō } \\
\text { Kōkō Kyōyu) no Shigoto [An oral } \\
\text { history regarding the training of } \\
\text { engineers during the high economic } \\
\text { growth period - The work of Mr. } \\
\text { Isamu Tachikawa (former teacher } \\
\text { at an industrial high school)] (one } \\
\text { interview)." Hōsei Daigaku Career } \\
\text { Design Gakubu Kiyō, no. 5, 2007. }\end{array}$ & $\begin{array}{l}\text { Former industrial high school } \\
\text { teacher who supported the } \\
\text { employment of students }\end{array}$ & Umezaki, Osamu. Senō, Wataru. \\
\hline
\end{tabular}




\begin{tabular}{|l|l|l|}
\hline $\begin{array}{l}\text { Shimizu, Katsuhiro, Akitake } \\
\text { Taniguchi and Teiichi Sekiguchi. } \\
\text { Dankai no Sedai no Shigoto to } \\
\text { Career - Nihon no Daikigyo ni } \\
\text { okeru Daisotsu Elite no Oral } \\
\text { History [Jobs and careers of the } \\
\text { baby boomers - Oral histories of } \\
\text { elites with tertiary education } \\
\text { employed by Japanese large } \\
\text { companies] (five interviews). }\end{array}$ & $\begin{array}{l}\text { Shimizu, Katsuhiro. Taniguchi, } \\
\text { Akitake. Sekiguchi Teiichi. } \\
\text { Tokyo: Chūō University Press, } \\
\text { 2019. }\end{array}$ & $\begin{array}{l}\text { Ichihara, Hiroshi. Umezaki, Osamu } \\
\text { et al. }\end{array}$ \\
\\
\hline
\end{tabular}

\section{Oral Histories regarding Trade Unions in the Machinery and Metal Industries}

Oral history studies regarding trade unions in the machinery and metal industries started when the GRIPS project conducted an interview with Amaike Seiji, former Kaichō [Chairman] of the Dōmei [Japan Confederation of Labor], with Itō Takashi as the main interviewer. After this project, Umezaki Osamu received grants including the Kakenhi [Grants-in-aid for Scientific Research] and, together with Nagumo Chiaki and Shimanishi Tomoki, conducted interviews with Hayashi Fujio, former Kaichō of the Tokyo Dōmei [Japan Confederation of Labour, Tokyo] and Ishihara Toshiaki, former Iinchō [Chairman] of the Zenkin Dōmei Osaka [Japan Federation of Metal Workers' Unions, Osaka] and also Kaichō of the Osaka Rengō [Japanese Trade Union Confederation, Osaka], in addition to both employers and union leaders involved in the conclusion of the Tokyo Metal Workers' Unified Labor Agreement. All of these oral histories are about trade unions associated with the Sōdōmei [Japan Federation of Labour] or the Dōmei. On the other hand, with regard to the Zenkoku Kinzoku [National Federation of Metal and Engineering Workers' Unions], which was affiliated with the Sōhyō [the General Council of Trade Unions of Japan], a rival organization of the Dōmei, Hirasawa Eiichi, a former leader of the Zenkoku Kinzoku, was interviewed. Moreover, in an interview with the Sōhyō Zenkin Sumitomo Jūkikai Kōgyō Shibu [Sumitomo Heavy Industries Branch], a story of an internal struggle within a company-based union was told.

\section{Oral Histories regarding Industrial Relations in the Electrical Industry}

As for the electrical industry, the attempt of oral history started when the GRIPS project interviewed, with Inoki Takenori as the main interviewer, Takahata Keiichi, former Iinchō [Chairman] of the Matsushita Denki Rōren [Matsushita Electric Branch of the All-Japan Federation of Electric Machine Workers' Unions] who played a crucial role in the unification of the labor front. Then, Tateyama Toshifumi was interviewed, who became Kaichō [Chairman] of the Minkan Rengō [All-Japan Council of Private Sector Trade Unions] at the request of the Denki Rengō [Japanese Electrical, Electronic \& Information Union]. Thereafter, Umezaki Osamu received grant support, increased the number of researchers and conducted interviews with leaders of the Denki Rōren: namely, Warashina Mitsuharu, Sakioka Toshikatsu and Katō Noboru. The interviews with Yoshimura Toshio and Kuno Osamu are about activities of a company-based union at the Mitsubishi Electric and those with Umehara Shirō, about a job at the personnel department of the Tōshiba Electric. 


\section{Oral Histories regarding the Zensen Dōmei [Japanese Federation of Textile Workers' Unions] (present-day the UA Zensen [Japanese Federation of Textile, Chemical, Food, Commercial, Service and General Workers' Unions])}

Oral histories regarding the Zensen Dōmei started with the GRIPS project's interview with Usami Tadanobu, former Kaichō [Chairman] of the Zensen Dōmei and Kaichō of the Dōmei [Japan Confederation of Labour], in which Itō Takashi assumed the role of the main interviewer. This interview gives, as does the interview with Amaike Seiji, former Kaichō of the Dōmei, an excellent account of the Dōmei's industrial strategies as well as activities of the Zensen Dōmei. Then, Umezaki Osamu and Nagumo Chiaki found funding and implemented more interviews: with Satō Fumio, Wada Tadashi, Noguchi Naoya, Ninomiya Makoto, Sugai Yoshio, Ochiai Kiyoshi and Tokuda Kōzō. They are former members of industrial unions who played key roles as organizers and policy-makers. If these oral histories are read in chronological order, the history of the Zensen Dōmei can be grasped. On the other hand, the oral histories concerning Yamanaka Yōsuke and the Ōmi Kenshi Human Rights Dispute are part of an oral history project on the history of the labor movement in Osaka implemented in collaboration with the Osaka Sangyō Rōdō Shiryōkan [Osaka Labor Archive]. The former helps understand activities of company-based unions affiliated with the Zensen Dōmei. The latter includes valuable testimonies to subjects related to the exemplary labor dispute of the 1950s: such as the formation of the trade union, the affiliation with the Zensen Dōmei and the confrontation between the pro- and antiZensen sides within the labor camp.

\section{Oral Histories regarding Industrial Relations in the Steel Industry}

Oral histories regarding the steel industry started when the GRIPS project conducted interviews with Miyata Yoshiji, former Kaichō [Chairman] of the IMJC and Iinchō [Chairman] of the Tekkō Rōren [Japan Federation of Steel Workers' Unions], and with Okuda Kenji, a former personnel officer at the NKK, with Inoki Takenori and Odaka Kōnosuke as the main interviewers, respectively. Then, the GRIPS project continued the interviews concerning the NKK: with Nishikawa Tadashi from the Personnel Department, with Gotō Tatsuo, Kunimoto Minoru, Tan'no Shōsuke and Iwasaki Kaoru from the trade union and also with some engineers. Thereafter, a project under the leadership of Itō Takashi carried out interviews with regard to subjects such as the Tekkō Rōren's wage policy and industrial relations in the steel industry. In addition, a project funded by the Grants-in-Aid for Scientific Research was set up under Umezaki Osamu's leadership. With Aoki Hiroyuki being the main researcher, this project conducted interviews with Oguri Hirotoyo, Serizawa Hisayoshi and Yokoyama Susumu, former leaders of the Tekkō Rōren, together with some engineers in the steel industry.

On the other hand, the Tokyo Daigaku Shakaikagaku Kenkyūsho [Institute of Social Science, University of Tokyo] organized a large project called "Kibo no Shakaikagaku [social sciences of hope]." One of its research teams, which was led by Nakamura Naofumi and included Nitta Michio, Aoki Hiroyuki and Umezaki Osamu, conducted interviews with both managerial officers and workers at the Kamaishi Steel Works run by the Fuji Seitetsu [Fuji Steel (later Nippon Steel)].

\section{Oral Histories of Trade Unions in the Shipbuilding Industry}

As for the shipbuilding industry, the GRIPS project implemented an interview with Kanasugi Hidenobu, former Iinchō [Chairman] of the Zōsen Jūki Rōren [Japan Federation of Shipbuilding and Heavy Industries Workers' Unions] with Itō Takashi as the main interviewer. Then, the project was continued under the leadership of Itō Takashi and conducted an interview with Itō Sukesada, also former Iinchō of the Zōsen Jūki Rōren. The author took part in this project as one of the interviewers. 


\section{Oral Histories concerning the Productivity Movement}

The focus of the oral history studies concerning the Productivity Movement was not on individual persons or specific subjects but on the organization's activities. This GRIPS project, planned by Umezaki Osamu, involved Ishida Mitsuo, Fujimura Hiroyuki, Shibata Hiromichi and others as interviewers. At the request of the United States, the Productivity Movement was started by the Organization for European Economic Cooperation (OEEC), which had been established in 1948 as part of the Marshal Plan. The Nihon Seisansei Honbu [Japan Productivity Center] was set up in 1955 under the initiative of the Keizai Dōyūkai [Japan Association of Corporate Executives] for the following two purposes: the prevention of unemployment through labor-management cooperation and technological development and the realization of fair distribution between employers, employees and consumers. With regard to the Japan Productivity Center, opinions varied even among trade unions. The project interviewed officers from three different departments of the Center: Rōdō-bu [Labor Department] which dealt with industrial relations; Kokusai-bu [International Department] which organized international inspections; and Keiei Kaihatsu-bu [Management Development Department] which was in charge of management support. The research team first studied the changes of senior officers through internal materials, and then selected candidates for the interviews from among both active and retired officers. Moreover, the project implemented an interview with Murasugi Yasuo. Then, after having gained funding, it carried out oral histories of those officers who participated in the overseas inspections organized by the International Department.

By the way, in the case of oral history studies on organizations, there is a risk that people with rather biased views are chosen as storytellers, because candidates for interviews are introduced through personal connections. In fact, during the preparation process of the interviews concerning the Labor Department, the storytellers, namely, Kawanabe Iwao, Maeda Akio and Nakajō Kuramitsu, were found and selected through multiple connections in consideration of an intra-department conflict.

\section{Oral Histories regarding Labor Management}

Oral histories of personnel and labor management officers were commenced after the completion of the GRIPS oral history project concerning the Productivity Movement. Fujimura Hiroyuki and Ishida Mitsuo continued to assume the roles of interviewers. Hyōdō Tsutae was Jinji-buchō [Head of the Personnel Department] of the Sumitomo Jūkikai Kōgyō [Sumitomo Heavy Industries] and attended various committees of the Japan Productivity Center. The trade union of the Sumitomo Heavy Industries had been affiliated with the Sōhyō Zenkoku Kinzoku [National Federation of Metal and Engineering Workers, the General Council of Trade Unions of Japan], but later withdrew from it. Next, Kusuda Kyū was originally an officer at the Rōdō-shō [Ministry of Labor] in charge of wage policies and systems, but then quit the job to become a wage consultant. He made a considerable contribution to the designing and popularization of the Shōkunō Shikaku Seido [ability-based grading system] and Shokunō-kyū [job-evaluation-based wages]. Thanks to the oral history method, the evolution of wage system designs was traced and the expertise required for the introduction of the new system was disclosed.

After the termination of the GRIPS project, interviews were continued with wage consultants connected to Kusuda as well as personnel officers at private companies who had been the members of the same committees as Kusuda's and exchanged opinions with him about wage systems. As a result, 'Shōkunō Shikaku Seido to Shokunō-kyū' Oral History [Oral histories concerning the ability-based grading system and job-evaluation-based wages] was produced. Next, personnel officers and management consultants who had contributed to the designing of the personnel system were interviewed. 
These interviews resulted in Sengo Chingin Seidoshi Oral History [Oral histories regarding the postwar wage system] and Kagiyama Yoshimitsu Oral History [The oral history of Kagiyama Yoshimitsu].

In addition, the Keiō Gijuku Daigaku Sangyō Kenkyūsho [Keio Economic Observatory] organized, under Yashiro Atsushi's leadership, an oral history project as to the Nihon Keieisha Dantai Renmei (Nikkeiren) [Japan Federation of Employers' Associations], which was referred to at the time as the personnel department of the Japanese business community. The project's attention was drawn to the Shokumu Bunseki Center [Center for Work Analysis] established by the Nikkeiren and two books, Nōryokushugi Kanri - Sono Riron to Jissen [Performance-based human resource management - Theory and practice] and Shinjidai no 'Nihonteki Keiei' - Chōsen Subeki Hōkō to Sono Gutaisaku [The Japanese-style management in a new era - The direction we should choose and concrete measures] published in 1969 and 1995, respectively. Hence, the authors of the articles in these books were interviewed. The interviews are historical records which show the changes in HR practices: that is, from the job-based ones, through the performance-based ones, to the Japanese-style employment portfolio. Moreover, the Keio Economic Observatory also carried out interviews concerning the employment and industrial relations at the Nissan Motor for the purpose of investigating HR practices during the 2000 s.

\section{Oral Histories regarding Labor History Records}

There is an oral history workshop specialized in labor history records. In this workshop, interviews are conducted concerning how written materials related to labor history have been collected and deposited. A lot of historical documents are yet to be properly classified and preserved. Therefore, oral history records concerning records of historical documents would help raise the utilization of both types of records.

\section{Other Oral Histories}

There are other oral histories which are difficult to categorize. The GRIPS project implemented, with Itō Takashi as the main interviewer, oral histories of Takaragi Fumihiko, former Iinchō [Chairman] of the Zentei [Japan Postal Workers' Union], and Yamagishi Akira, former Kaichō [Chairman] of the Rengō [Japanese Trade Union Confederation] and Iinchō of the Zen Den Tsū [National Telecommunications Workers' Union]. These are historical records which give an account not only of activities of the Kan Kō Rō [Government and Public Workers' Union] but also of how trade union leaders acted for the establishment of a unified national center. If these oral histories are read side by side with those of Amaike Seiji, Miyata Yoshiji, Takahata Keiichi, Kashiyama Toshifumi, Usami Tadanobu, Kanasugi Hidenobu and so on, internal struggles and negotiations concerning the future direction during the formation process of the Rengō can be grasped.

Apart from them, there are also oral histories regarding the Zenkoku Ippan [National Union of General Workers] and the Nikkyōso [Japan Teachers' Union]. Moreover, "Kōdo Seichōki ni okeru Gijutsusha Yōsei no Oral History [An oral history regarding the training of engineers during the high economic growth period]" is a collection of interviews with industrial high school teachers in which subjects such as education and employment support were brought up. Furthermore, Dankai no Sedai no Shigoto to Career - Nihon no Daikigyō ni okeru Daisotsu Elite no Oral History [Jobs and careers of the baby boomers - Oral histories of elites with tertiary education employed by Japanese large companies] (Tokyo: Chūō University Press, 2019) is a result of a project organized by the Chūō Daigaku Kigyō Kenkyūsho [Institute of Business Research, the Chūo University]. This project traced the careers of five persons who graduated from the Economics Department of the Kyoto University at the same 
time in 1972. It is an attempt to analyze the employment situation in Japan, applying the same standards as to conditions such as educational background and age.

\section{Future Tasks and Prospects}

This article has presented an overall picture of labor oral histories in Japan. Although the author's document retrieval is not complete, this article would encourage historians to utilize Japanese oral histories as it gives their general outline to researchers both within and outside the country. From this point of view, this is only a trial version on which revisions will be made continually.

While oral histories accumulates, the difficulty in their retrieval remains. Therefore, it is a future task to create an open database of oral histories which can be updated at any time, rather than to publish articles like this one. In fact, a database is now being built, in which searching can be done by index items such as storyteller, interviewer and publisher. In order to make it open to the general public, however, the establishment of an oral history center is necessary which, as in the case of those in Europe and the United States, preserves oral history records while allowing open access (Umezaki 2016 b).

The establishment of such an organization that guarantees the accessibility of its records would exert a positive influence on the implementation of oral histories. As was mentioned earlier, the author holds that open access to oral history records, which makes possible source criticism, is a crucial requisite for oral histories to be assigned a primary role in historical researches, instead of a secondary, or complementary, role. On the other hand, however, it is a fact that if every spoken word in the interview is put into written words and published in the form of a booklet after editing, such a project will consume too much effort and money. It can be said, therefore, that although the utilization of oral histories is promoted by their openness, the required process to make them open is holding back the implementation of oral histories.

Finally, with respect to future prospects, the following three points should be noted. First, surveys of oral history studies should receive proper appreciation from researchers. It is by writing and publishing reviews and bibliographical notes of oral histories implemented that their source criticism is made possible. By receiving appreciation and criticism in this way, the significance of oral history studies will be enhanced, and then they will be worth the effort and money spent.

Second, the establishment of an oral history archive run by a reliable organization is required to carry out more efficiently the task of preserving oral history records while guaranteeing their public accessibility. Even if an audio record to which only its rough outline, or a note of its contents, is attached is given free accessibility, it can still be said that "it is open to the public" as long as researchers have free access to it. However, such open accessibility is only possible when a facility run by a reliable organization guarantees the preservation of the records and their free accessibility on a long-term basis. In Europe and the United States, Umezaki $(2016$ b) points out, it is possible to deposit a plain audio record to an oral history center. In Japan, however, there is no such facility. Therefore, for historians who have implemented oral history studies, the only way to surely preserve oral history records for the future is to produce booklets and send them to libraries.

Third, audio and video records are more difficult to edit relative to transcripts, and the required procedure to make them open to the public is more complicated. The author is now running a web page titled "Rōdōshi Oral History Archive" in collaboration with the Osaka Sangyō Rōdō Shiryōkan [Osaka Labor Archive]. The editing work is more demanding relative to the handling of transcripts, and the procedure for public disclosure is more troublesome (Umezaki 2016 a). The procedure needs to be more simplified and manualized in the future. 


\section{Acknowledgements}

This study is supported by the Kakenhi [Grants-in-Aid for Scientific Research], "Kiban Kenkyū B: Sengo Rōdōshi ni okeru Oral History Archive Ka no Kisoteki Kenkyū [Basic research B: A basic study on the creation of a labor oral history archive (No. 23330115)." I would like to express my gratitude.

\section{Reference}

Chizuka, Tadami. Shigaku Gairon [An introduction to history]. Tokyo: University of Tokyo Press, 2010.

Itō, Takashi. "Kikitori ni tsuite [On hearing investigation]." In Kindai Nihon Kenkyū Nyūmon [An introduction to the study of modern Japan], edited by Nakamura, Takafusa and Takashi Itō, 279-286. Tokyo: University of Tokyo Press, 1977.

---. "Rekishi Kenkyū to Oral History [Historical research and oral history].” In Jinbun Sakai Kagaku Kenkyū to Oral History [Social sciences, humanities and oral history], edited by Ōhara Shakaimondai Kenkyūsho [the Ōhara Institute for Social Research, Hōsei University], 3-19. Tokyo: Ochanomizu Shobō, 2009.

Mikuriya, Takashi. Oral History - Gendaishi no tameno Kōjutsu Kiroku [Oral history - Interview records of modern history]. Tokyo: Chūō Kōrōn Shinsha, 2002.

---, ed. Oral History Nyūmon [An introduction to oral history]. Tokyo: Iwanami Shoten, 2007.

---, ed. Oral History ni Nani ga Dekiruka: Tsukurikata kara Tsukaikata made [What can oral history do?: From how to make it to how to use it]. Tokyo: Iwanami Shoten, 2019.

Nakamura, Masanori. "Oral History to Rekishigaku [Oral history and the discipline of history]." Rekishigaku Kenkyū [Journal of historical studies], no. 568 (1987): 2-6.

Odanaka, Naoki. "Gengoronteki Tenkai to Rekishigaku [The linguistic turn and history]." Shigaku Zasshi [Historical journal of Japan], vol. 109, no. 9 (2000): 1686-1706.

Ōkado, Masakatsu. Kataru Rekishi, Kiku Rekishi - Oral History no Genba [History is speaking, listening to history - oral history workshop]. Tokyo: Iwanami Shoten, 2017.

Rekishigaku Kenkyūkai [Historical Science Society of Japan], ed. Jijitsu no Kenshō to Oral History: Sawachi Hisae no Shigoto o Megutte [Fact-checking and oral history: About Hisae Sawachi’s work]. Tokyo: Aoki Shoten, 1988 a.

---, ed. Oral History to Taikenshi: Honda Katsuichi no Shigoto o Megutte [History and stories of experiences: About Katsuichi Honda's work]. Tokyo: Aoki Shoten, 1988 b.

Thomson, Paul. The Voice of the Past: Oral History, third edition. Oxford: Oxford University Press, 2000. Translated into Japanese by Sakai, Junko. Kioku kara Rekishi e - Oral History no Sekai. Tokyo: Aoki Shoten, 2002.

Ueno, Chizuko, ed. Kozōshugi toha Nanika [What is stucturalism?]. Tokyo: Keisō Shobō, 2001.

Uesugi, Shinobu. "America ni okeru Oral History no Genjō to Sono Seika [The real state and results of oral history studies in the United States]." In Jijitsu no Kenshō to Oral History: Sawachi Hisae no Shigoto o Megutte [Factchecking and oral history: About Hisae Sawachi's work], edited by the Rekishigaku Kenkyūkai [Historical Science Society of Japan], 140-170. Tokyo: Aoki Shoten, 1988.

Umezaki, Osamu. "Rōdō Kenkyū to Oral History [Labor studies and oral history]." In Jinbun Sakai Kagaku Kenkyū to Oral History [Social sciences, humanities and oral history], edited by Ōhara Shakaimondai Kenkyūsho [the Ōhara Institute for Social Research, Hōsei University], 155-181. Tokyo: Ochanomizu Shobō, 2009.

---. “Oral History ni yotte Nani o Bunseki Surunoka - Rōdōshi ni okeru 'orality' no Kanōsei [What is analyzed by oral history? - The possibility of 'orality' in labor history].” Shakai Seisaku, 11 (2012): 32-44. 
---. "Rōdōshi Oral History Archive no Kokoromi - Eizōka no Torikumi to Shiryō no Riyōkanōsei o Chūshin ni [An attempt to create a labor oral history archive - Video materials and the usability of various types of records]." Shakai Seisaku, vol. 7, no. 3 (2016 a): 102-112.

---. "Eibei no Oral History Archive kara Nani o Manabu ka [What should we learn from oral history archives in Europe and the United States]." Current Awareness, 330 (2016 b): 21-24.

Yoshida, Kenzi. "Ōhara Shakaimondai Kenkyūsho no Oral History[Oral history in Ōhara Shakaimondai Kenkyūsho]." In Jinbun Sakai Kagaku Kenkyū to Oral History [Social sciences, humanities and oral history], edited by Ōhara Shakaimondai Kenkyūsho [the Ōhara Institute for Social Research, Hōsei University], 183-223. Tokyo: Ochanomizu Shobō, 2009. 